Article

\title{
An Organic-Inorganic Hybrid Nanocomposite as a Potential New Biological Agent
}

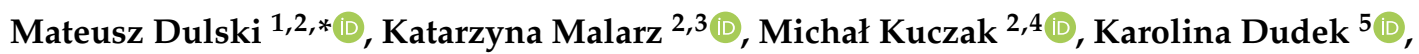 \\ Krzysztof Matus $^{6}{ }^{(D}$, Sławomir Sułowicz ${ }^{7} \mathbb{D}$, Anna Mrozek-Wilczkiewicz ${ }^{2,3}$ and Anna Nowak ${ }^{8}$ \\ 1 Institute of Materials Engineering, University of Silesia, 75 Pulku Piechoty 1a, 41-500 Chorzow, Poland \\ 2 Silesian Center for Education and Interdisciplinary Research, 75 Pulku Piechoty 1a, 41-500 Chorzow, Poland; \\ katarzyna.malarz@us.edu.pl (K.M.); mkuczak@us.edu.pl (M.K.); \\ anna.mrozek-wilczkiewicz@us.edu.pl (A.M.-W.) \\ 3 A. Chełkowski Institute of Physics, University of Silesia, 75 Pulku Piechoty 1, 41-500 Chorzow, Poland \\ 4 Institute of Chemistry, University of Silesia, Szkolna 9, 40-007 Katowice, Poland \\ 5 Łukasiewicz Research Network - Institute of Ceramics and Building Materials, Refractory Materials Division \\ in Gliwice, Toszecka 99, 44-100 Gliwice, Poland; karolina.dudek@icimb.lukasiewicz.gov.pl \\ 6 Materials Research Laboratory, Silesian University of Technology, Konarskiego 18a, 44-100 Gliwice, Poland; \\ krzysztof.matus@polsl.pl \\ 7 Institute of Biology, Biotechnology and Environmental Protection, University of Silesia, Jagiellonska 28, \\ 40-032 Katowice, Poland; slawomir.sulowicz@us.edu.pl \\ 8 Institute of Nuclear Physics Polish Academy of Sciences, PL-31342 Krakow, Poland; \\ ana.maria.nowak@gmail.com \\ * Correspondence: mateusz.dulski@smcebi.edu.pl
}

Received: 20 November 2020; Accepted: 15 December 2020; Published: 18 December 2020

\begin{abstract}
To solve the problem of human diseases caused by a combination of genetic and environmental factors or by microorganisms, intense research to find completely new materials is required. One of the promising systems in this area is the silver-silica nanocomposites and their derivatives. Hence, silver and silver oxide nanoparticles that were homogeneously distributed within a silica carrier were fabricated. Their average size was $d=(7.8 \pm 0.3) \mathrm{nm}$. The organic polymers (carboxymethylcellulose (CMC) and sodium alginate (AS)) were added to improve the biological features of the nanocomposite. The first system was prepared as a silver chlorine salt combination that was immersed on a silica carrier with coagulated particles whose size was $d=(44.1 \pm 2.3) \mathrm{nm}$, which coexisted with metallic silver. The second system obtained was synergistically interacted metallic and oxidized silver nanoparticles that were distributed on a structurally defective silica network. Their average size was $\mathrm{d}=(6.6 \pm 0.7) \mathrm{nm}$. Physicochemical and biological experiments showed that the tiny silver nanoparticles in $\mathrm{Ag} / \mathrm{SiO}_{2}$ and $\mathrm{Ag} / \mathrm{SiO}_{2} @ \mathrm{AS}$ inhibited E. coli, P. aeruginosa, S. aureus, and L. plantarum's cell growth as well as caused a high anticancer effect. On the other hand, the massive silver nanoparticles of $\mathrm{Ag} / \mathrm{SiO}_{2} @ \mathrm{CMC}$ had a weaker antimicrobial effect, although they highly interacted against PANC-1. They also generated reactive oxygen species (ROS) as well as the induction of apoptosis via the p53-independent mechanism.
\end{abstract}

Keywords: chemical reduction; silver-silica nanocomposite; carboxymethylcellulose; sodium alginate; physicochemical features; antimicrobial activity; anticancer activity; colon cancer; breast cancer; pancreatic cancer; glioblastoma

\section{Introduction}

Progress in biomedicine is closely related to the still-developing nanotechnology. In this context, nanotechnology enables novel multifunctional materials to be fabricated that contribute to improving 
everyday life [1], e.g., engineering new medicines in combination with porous materials/carriers or well-known organic or inorganic materials to be scaled-down into the "nano" range. Both approaches have advantages and disadvantages because the first route is designed to increase the drug selectivity of the action, while the second route may cause a higher dispersion of the material, which might translate into an increase in clinical effectiveness [2,3]. Hence, nanotechnology is expected to offer the possibility to change the form of the materials that are already being used and improve their functionality and properties [4].

Another route for improving the biological features of systems using a molecularly desired structure is its combination with polysaccharides, which have been explored in their natural state in nanomedicines for many years [5]. In this context, polysaccharides are classified into three types according to their origin: vegan (e.g., starch, cellulose, pectin), animal (e.g., chitin, heparin), and microbial/fungal (e.g., dextran. alginate) [5], wherein all of them can be considered to be carriers, especially in injectable drug delivery systems. Unfortunately, in this field, their stabilizing properties are still a challenge. Therefore, new methods for utilizing polysaccharides, especially for improving their physicochemical properties as well as their biomedical potential, are still being sought. Alginates, including sodium alginate (AS), which are cell-wall constituents of brown algae or a cellulose derivative such as carboxymethylcellulose (CMC), are increasingly common in various industries. Sodium alginate can be easily gelled in an acid medium. Due to its high similarity to extracellular matrices of living tissues, it can prepare materials to heal wounds or deliver bioactive agents such as drug proteins. AS can also be used to encapsulate materials, which causes the slow-release of a metallic nanostructure [6] or drugs [7] into cells in a controlled manner. Hence, alginate-based hydrogels or composite derivatives can be systems that can potentially be used to deliver nanostructures into the interior of cells [8,9]. It can also be used to help cure gastroesophageal reflux in children [10]. In turn, its non-antigenicity or mucoadhesiveness makes AS an ideal material for creating dental impressions, wound dressings, or engineering tissue [11]. In turn, CMC is widely used in biomedical applications and detergents, textiles, paper, food, and oil exploration [12]. It is also used as an emulsifying agent to improve a system's viscosity and prevent material from settling when being stored [13]. It has well-wetting and valuable features for particle coagulating or gluing due to its excellent film-forming properties. CMC's adhesive features could be useful for improving bonding particles to a base or carrier during the manufacturing process.

Other papers have also reported that polysaccharides can be used as a carrier for metallic nanoparticles, improving wound healing on the one hand or acting as a biological agent on the other [14]. The latter application, especially within developing new types of anticancer materials, has aroused the broadest interest. Cancer is a multifaceted disease caused by a complex combination of genetic and environmental factors that require a multistage treatment [15]. There are several therapeutic methods, and many of them are focused on using therapies that affect the entire body, not only the pathogenically changed site. Targeted treatments seem to be one of the most desirable solutions, and silver nanoparticles (Ag NPs) or silver-based hybrid systems can be considered one of the potentially new therapeutic agents. According to the literature, Ag NPs can cause cytotoxicity in cancer cells through various mechanism that involve oxidative stress [16-19], DNA damage [20], cell cycle arrest $[17,19,21,22]$, apoptosis and necrosis [16,23,24]. Lin et al. demonstrated that silver nanoparticles could induce cytoprotective autophagy, which improves the efficacy of Ag NPs in anticancer therapy [25].

Unfortunately, the lack of understanding of nanotoxicology and the biological activity of silver nanoparticles limits their usefulness. These might be associated with their aging process [26], thermal stability [27] or oxidation [28,29], as well as their shape, size [30-34], morphology [35-37], or degree of silver agglomeration [34,38,39]. Therefore, using a combination of Ag NPs with polysaccharides seems to be an idea that could reduce the number of silver ions released into the environment and reduce their toxicity. Augustine and Rajarathinam showed that a combination of Ag NPs with alginate reduced the toxicity of the silver ions released from silver nanoparticles and improved wound healing [40]. The 
same effect was observed in CMC by Kumar et al. [41] and Prema et al. [42]. Unfortunately, there is a growing bacterial resistance to silver, which is alarming when searching for new antibiotics. Therefore, using polysaccharides seems to be an interesting direction that might stabilize the silver-based systems. Unfortunately, some negative aspects of such an approach to the organic-inorganic system were revealed by Lengert et al., who showed that the influence of ultrasounds influences nanoparticles' release from such a capsule [43]. Hence, another carrier must improve the stability of silver and ensure its slow release from the matrix.

Recently, there have been many papers in the literature that have highlighted an innovative approach for functionalizing well-known structures by combining porous materials such as an oxide matrix carrier, e.g., a polymer, silicon oxide, titanium oxide, or zinc oxide, with the ionic form of metals or with metallic nanoparticles [44-47]. The chemically modified fumed silica seems to be the most promising inorganic structure due to the immobilization of silver on the surface via unsaturated chemical bonds [48]. Another advantage of such a molecular combination is that the unsaturated -Si-O* bonds, which is the biological factor, improve the response of the bioactive materials at their interface [49]. However, the effectiveness of the biological interaction of $\mathrm{Ag} / \mathrm{SiO} \mathrm{O}_{2}$ depends strongly on the type of reagents and their concentration in a solvent, chemical purity (>99.999\%), stabilizing agents (glycerin, polyethylene glycol, organic polymers, etc.), physical conditions (temperature, precursor, reactant concentration, microwave field, etc.) [50], and the manufacturing procedure that is used such as chemical reactions [50-52], sol-gel [53], or sputtering deposition [54]. These factors and methods provide an opportunity to control the physical parameters of a chemical reaction. An interesting approach to fabricating hybrid structures could also be modifying a chemical procedure by using polysaccharides to stabilize the silver or even encapsulate a silver-silica composite to improve the initial material's biological features.

Therefore, this paper illustrates a new approach to developing bioactive modified silver-silica structures, especially in the chemical modification of such molecular structures using the commercially available polysaccharides (carboxymethylcellulose and sodium alginate). The impact of all of the components on the shape, size, and morphology of a particle as well as its phase composition was determined using X-ray diffraction (XRD), scanning (SEM), and transmission (TEM) electron microscopy. The molecular interactions and structural parameters were investigated using Raman spectroscopy. The electronic structure and oxidation state of the silver were determined using X-ray photoelectron spectroscopy (XPS). Lastly, the structural and chemical parameters were correlated with the antimicrobial activity as well as the cytotoxicity on a group of cancer cells that included colon (HCT116), breast (MCF-7), pancreatic (PANC-1), and brain (U-251) cancers. The synthesized nanocomposites' impact on inhibiting the cell cycle and inducing apoptosis by generating reactive oxygen species (ROS) in the pancreatic cells was also examined. Therefore, the developed nanocomposites have the potential to be new, biologically active agents.

\section{Materials and Methods}

\subsection{Synthesis}

All of the primary chemical ingredients such as the silver nitrate, sodium hydroxide (purity above 99.99\%; Avantor Company, Gliwice, Poland), amorphous silica (Orisil 380; Orisil Ltd., Lviv Ukraine), and technical grade organic polymers such as carboxymethylcellulose (CMC) and sodium alginate (AS) were used. The technical CMC was a mixture of sodium chloride and sodium glycolate, while AS contained a residual fraction of sodium hypochlorite or chlorine dioxide. Distilled water was used to prepare all of the samples.

The silver-silica nanocomposite synthesis and its derivatives were carried out in two stages (Figure 1). The first step was preparing the carrier, i.e., $10 \mathrm{~g}$ silicon dioxide mixed with $200 \mathrm{~mL}$ of water. Next, the aqueous silica solution was subjected to microwave irradiation for $120 \mathrm{~s}$ to activate the silica's surface. A $4 \%$ aqueous sodium hydroxide solution and then silver nitrate was added dropwise 
into the silica suspension in the final step. The silica suspension was continuously mixed at room temperature on a magnetic stirrer for $1 \mathrm{~h}$. The result was a silver-silica colloid. The final product was filtered on a polyethylene filter, washed, and dried at room temperature (route A in Figure 1).
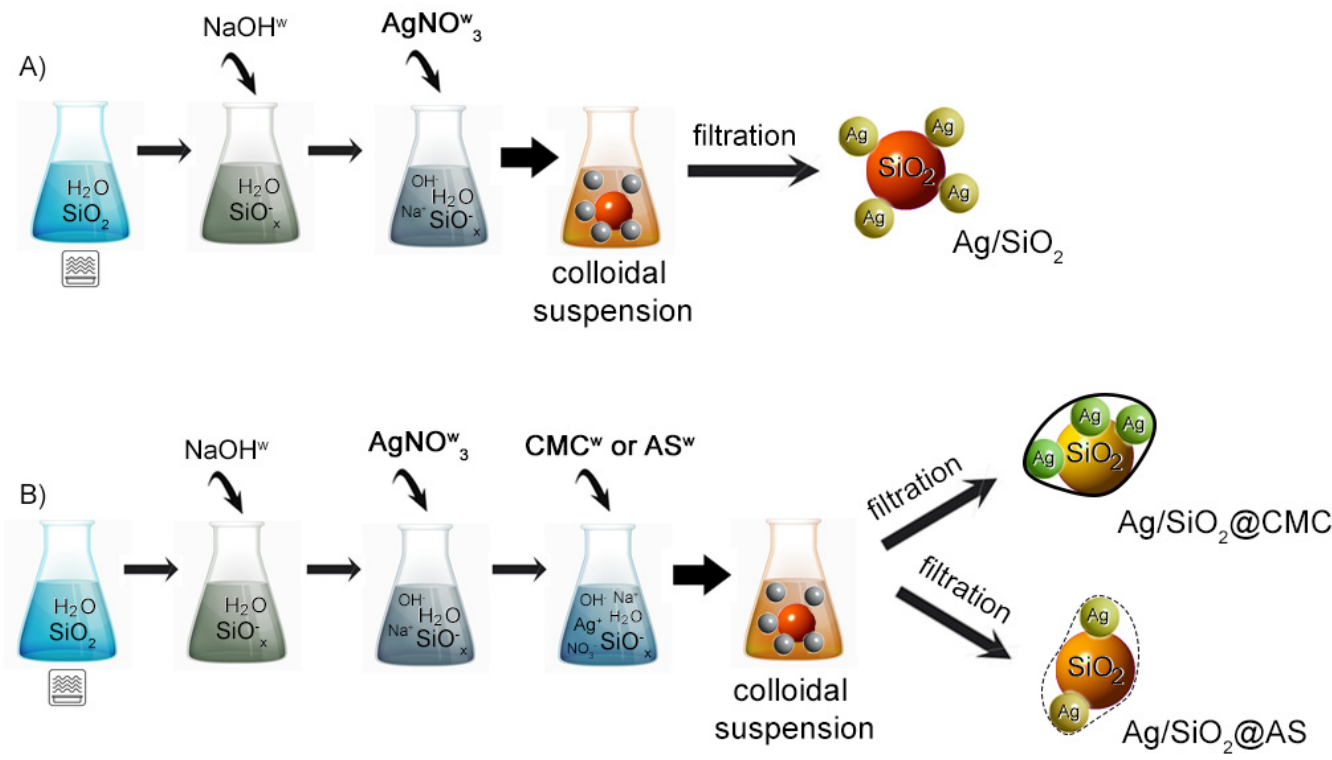

Figure 1. Two synthesis routes (A,B) were considered to fabricate the powder (A) silver-silica nanocomposite and $(\mathbf{B})$ its derivatives.

A similar procedure was used to fabricate the hybrid organic-inorganic systems. The silver-silica colloid was prepared as before. However, a $4 \%$ aqueous CMC or AS solution was added dropwise to the suspension to encapsulate the silver-silica system and form a core-shell organic-inorganic composite (route B in Figure 1). Lastly, both samples were filtered twice on a polyethylene filter, washed, and dried at room temperature to remove any impurities due to the synthesis.

\subsection{Experimental Methods}

An X'PertPro MPD PANalytical (Malvern PANalytical, Almelo, The Netherlands) X-ray diffractometer with a $\mathrm{Cu} \mathrm{K \alpha}$ radiation $(\lambda=1.54 \AA$ ) was used to obtain the crystal structure of the $\mathrm{Ag} / \mathrm{SiO}_{2}$ composite. The lattice parameters were refined using the Rietveld method with HighScore Plus (version 4.9) software (Malvern PANalytical, Almelo, The Netherlands) and the ICCD PDF-4+ database. The crystallite size was analyzed based on the change of the profile widths compared to a standard sample according to the Scherrer equation in HighScore Plus version 4.8. Calcite was used as the standard sample.

Particle morphology was determined using Scanning (SEM) and Transmission (TEM) Electron Microscopy with energy dispersive spectrometer (EDS). By contrast, the individual elements' surface chemical distribution was studied using a scenning electron microscopy SEM and X-ray photoelectron spectroscopy (XPS). The scanning electron microscopy (SEM) data were obtained using a TESCAN Mira 3 LMU equipped with an energy dispersive spectrometer (EDS) (TESCAN, Brno, Czech Republic). Images were collected with secondary electron (SE) and backscattered electron (BSE) detectors. Samples covered with a carbon layer were measured using Quorum Q150T Equipment (United Kingdom) to compensate for the charge of the system. The TEM micrographs were collected using a probe $\mathrm{C}_{\mathrm{s}}$-corrected S/TEM Titan 80-300 FEI (FEI Company, Hillsboro, OR, USA) microscope equipped with an EDAX EDS detector. The images were recorded in high resolution scanning transmission electron microscopy (HRSTEM)-mode using a high-angle annular dark-field (HAADF) detector. The XPS measurements were collected using a Prevac and VGScienta spectrometer (Newburyport, MA, USA). Monochromatic $\mathrm{Al} K_{\alpha}$ radiation $(1486.6 \mathrm{eV})$ was used to collect the broad energy range survey spectra as 
well as the spectra of the core levels, including $\mathrm{Ag} 3 d, \mathrm{O} 1 s, \mathrm{Si} 2 p$, and $\mathrm{Cl} 2 p$. The chemical composition and oxidation states within the initial $\mathrm{Ag} / \mathrm{SiO}_{2}$ and its modification were also determined. The spectra were shifted relative to the carbon C 1 s line at $284.6 \mathrm{eV}$ and corrected for the background signal using the integrated Shirley algorithm. The bands were fitted by composing the Gaussian and Lorentzian lines using MultiPak (version 9.6.1.) software.

Structural analysis, especially characterizing the three-dimensional network of the silica and identifying the individual phases, was performed using Raman spectroscopy. A WITec Confocal Raman Microscope (CRM) alpha $300 \mathrm{R}$ equipped with an air-cooled solid-state laser $(\lambda=532 \mathrm{~nm})$ and a charge-coupled device (CCD) camera was used. The excitation laser radiation was coupled with a microscope using a single-mode optical fiber with a $50 \mathrm{~nm}$ diameter. An air Olympus MPLAN $(100 \times / 0.90 N A)$ objective was used during the measurements. The Raman scattered light was focused onto a multi-mode fiber (100 nm diameter) and a monochromator with a $600 \mathrm{line} / \mathrm{mm}$ grating. The Raman spectra were accumulated in 100 scans at an integration time of $20 \mathrm{~s}$ and a resolution of $3 \mathrm{~cm}^{-1}$. The spectrometer monochromator was calibrated using the Raman scattering line of a silicon plate $\left(520.7 \mathrm{~cm}^{-1}\right)$. The post-processing analysis, with the baseline correction and cosmic ray, was performed using WITecProjectFour (version 4.1) Plus software. The peak fitting was analyzed using the GRAMS (version 9.2) software package.

\subsection{Antimicrobial Properties of Nanocomposites-Spot Test}

The toxicity of $\mathrm{Ag} / \mathrm{SiO}_{2}$ and its modified derivatives, $\mathrm{Ag}^{+}$-ions, was examined against the microbial stains Gram-negative bacteria Escherichia coli and Pseudomonas aeruginosa, Gram-positive bacteria Lactobacillus plantarum and Staphylococcus aureus, and the yeast Candida albicans and Saccharomyces cerevisiae. The cell suspensions were prepared as was previously described [54,55]. Cell suspensions of $24 \mathrm{~h}$ bacterial and yeast culture (Luria Broth (LB) and and Yeast extract Peptone Dextrose (YPD) media, respectively, at $301 \mathrm{~K}, 160 \mathrm{rpm}$ ) were diluted in fresh growth medium and cultivated (301 K, $160 \mathrm{rpm})$ for four to six hours. When the mid-exponential growth phase for the bacteria $\left(\mathrm{OD}_{600 \mathrm{~nm}}=\right.$ $0.6)$ and yeast $\left(\mathrm{OD}_{600 \mathrm{~nm}}=0.8-1.0\right)$ was reached, the cell suspensions were centrifuged (4700 rpm for $10 \mathrm{~min}$ at $293 \mathrm{~K}$ ), the pellets were suspended in sterile demineralized (DI) water (Milli-Q, Millipore, Darmstadt, Germany) and centrifuged again. Finally, the cells were resuspended in DI water to a density of $\sim 10^{7} \mathrm{CFU} / \mathrm{mL}$ for the bacteria $\left(\mathrm{OD}_{600 \mathrm{~nm}}=0.1\right)$ and yeast $\left(\mathrm{OD}_{600 \mathrm{~nm}}=1.2\right)$ as was described by Suppi et al. [54].

Next, $30 \mu \mathrm{L}$ of the cell suspension was added to the $30 \mu \mathrm{L}$ of samples and ion forms of $\mathrm{Ag}^{+}$ $\left(\mathrm{AgNO}_{3}\right)$, treated as a reference. All of the samples were tested at six nominal concentrations: 0.01, 0.1, $1.0,10,100$, and $1000 \mathrm{mg} / \mathrm{L}$. The stock solutions $(2000 \mathrm{mg} / \mathrm{L})$ of the nanomaterials and $\mathrm{Ag}^{+}$were placed in sterile DI water and homogenized using an ultrasonic probe (PolSonic 3, Warsaw, Poland) at $2 \times 160$ $\mathrm{W}$ for $1 \mathrm{~h}$ immediately before the test. The stocks were diluted in DI water and the tested concentrations were distributed into 96-well microplates (BD Falcon). The test organisms were exposed to the samples in DI water at $297 \mathrm{~K}$ for $24 \mathrm{~h}$ without shaking in the dark. Each experiment was repeated three times.

After a $24 \mathrm{~h}$ exposure, $4 \mu \mathrm{L}$ of the cell suspension was pipetted as a 'spot' onto LB or YPD agar plates, which were incubated for $24 \mathrm{~h}$ (bacteria) or $72 \mathrm{~h}$ (yeast) at $301 \mathrm{~K}$. The formation of a visible 'spot' (colonies) was used to determine the ability of the tested organisms to grow on an agar medium. The minimum biocidal concentration (MBC) of the tested nanomaterials and ion forms of silver was determined as the lowest tested concentration of a chemical that completely inhibited the formation of visible colonies after subculturing on toxicant-free agar media.

\subsection{Anticancer Studies}

\subsubsection{Cell Culture}

The human colon carcinoma cell line HCT 116 and the human breast carcinoma cell line MCF-7 were obtained from ATCC. The human glioblastoma cell line U-251 was provided by the Institute of 
Cancer Research in London, England. The human pancreatic carcinoma cell line PANC-1 was purchased from Sigma Aldrich (Saint Luis, MO, USA). The cells were grown as monolayer cultures in $75 \mathrm{~cm}^{2}$ flasks (Nunc) in Dulbecco's modified Eagle's medium (DMEM). The DMEM was supplemented with 12\% heat-inactivated fetal bovine serum (Sigma, Saint Luis, MO, USA) and $1 \% v / v$ of penicillin/streptomycin (Gibco). The cells were cultured under standard conditions at $311 \mathrm{~K}$ in a humidified atmosphere at $5 \%$ $\mathrm{CO}_{2}$. All of the cell lines were subjected to routine mycoplasma testing using the PCR technique with specific Mycoplasma primers to ensure no contamination.

\subsubsection{Cytotoxicity Studies}

The tested nanocomposites, $\mathrm{Ag} / \mathrm{SiO}_{2}, \mathrm{Ag} / \mathrm{SiO}_{2} @ \mathrm{CMC}$, and $\mathrm{Ag} / \mathrm{SiO}_{2} @ \mathrm{AS}$, were dissolved in the culture medium to achieve the necessary concentrations. The exponentially growing cells were harvested by trypsinizing the sub-confluent cultures. The cells (HCT 116, MCF-7, U-251, PANC-1) were seeded into 96-well cell culture microtiter plates (Nunc, Roskilde, Denmark) at concentrations of 5000 cells per well and incubated at $310 \mathrm{~K}$ for $24 \mathrm{~h}$. After this time, the growth medium was exchanged for a medium containing the tested nanocomposites at concentrations ranging from 1 to $50 \mathrm{mg} / \mathrm{L}$. The cells were incubated with the nanocomposites for $72 \mathrm{~h}$ under standard cell culture conditions. Then, the medium was replaced with $100 \mu \mathrm{L}$ of DMEM without phenol red. The viable cells' metabolic activity was determined by adding $20 \mu \mathrm{L}$ of CellTiter 96AQueousOne Solutions-MTS (Promega, Medison, WI, USA) and followed by a $1 \mathrm{~h}$ incubation. The MTS assay is a colorimetric method that is used to determine the number of viable cells. Here, a standard solution containing $100 \mu \mathrm{L}$ of DMEM without phenol red and $20 \mu \mathrm{L}$ of an MTS solution was used to determine the "blank" absorbance. By contrast, the absorbance of $\mathrm{Ag} / \mathrm{SiO}_{2}$ was measured at $490 \mathrm{~nm}$ using a Synergy ${ }^{\mathrm{TM}} 4$ microplate reader (BioTek, Winooski, VT, USA). A 50\% inhibitory concentration $\left(\mathrm{IC}_{50}\right)$ was defined as the compounds' concentration that can reduce cell proliferation to $50 \%$ of the untreated control cells. Each compound was individually tested in triplicate in a single experiment, while each experiment was repeated four times. The $\mathrm{IC}_{50}$ values were calculated using GraphPad Prism (verion 7) software.

\subsubsection{Time-Dependent Measurement of the ROS Level}

The PANC-1 cells were seeded into black 96-well plates (Corning, Corning, NY, USA) at a density of 9000 cells/well and incubated at $310 \mathrm{~K}$. After incubating overnight, the tested nanocomposite $\mathrm{Ag} / \mathrm{SiO}_{2} @ \mathrm{CMC}(30 \mathrm{mg} / \mathrm{L})$ solution was added and then incubated for $1,3,6,9,12$, and $24 \mathrm{~h}$ in a kinetic experiment. The generation of ROS was measured using a CellROX ${ }^{\circledR}$ Green Reagent (Molecular Probes $^{\mathrm{TM}}$, Eugene, OR, USA). Additionally, the number of cells in each well was determined using Hoechst 33342 (Molecular Probes ${ }^{\mathrm{TM}}$ ). The tested compounds' solutions were removed, and $100 \mu \mathrm{L}$ of CellROX Green Reagent and Hoechst 33342 at a final concentration of $5 \mu \mathrm{M}$ were added to each well. Then, the cells were incubated for $30 \mathrm{~min}$ at $310 \mathrm{~K}$. The fluorescence was measured using a multi-plate reader (Synergy 4, Bio Tek, Winooski, VT, USA) at $485 \mathrm{~nm}$ excitation and a $520 \mathrm{~nm}$ emission for CellROX Green Reagent and a $345 \mathrm{~nm}$ excitation laser and a $485 \mathrm{~nm}$ emission filter for the Hoechst 33342. The experiments were each performed three to four times. The ROS levels are expressed as the percentage of the level of the control cells.

\subsubsection{Cell Cycle Assay}

The PANC- 1 cells were seeded in $3 \mathrm{~cm}$ Petri dishes (Nunc) at a density of $0.25 \cdot 10^{6}$ cells/well and incubated at $310 \mathrm{~K}$ for $24 \mathrm{~h}$. The medium was then removed, and freshly prepared solutions of the tested nanocomposites, $\mathrm{Ag} / \mathrm{SiO}_{2}, \mathrm{Ag} / \mathrm{SiO}_{2} @ \mathrm{CMC}$, and $\mathrm{Ag} / \mathrm{SiO}_{2} @ \mathrm{AS}$ were added at a $30 \mathrm{mg} / \mathrm{L}$ concentration. After a $48 \mathrm{~h}$ treatment, the assay was performed using a Muse Cell-Cycle Kit (Millipore, Burlington, MA, USA) according to the manufacturer's instructions. The cells were collected, washed with cold phosphate-buffered saline (PBS), and centrifuged at $300 \times g$ for $5 \mathrm{~min}$. Then, the cells were fixed in ice-cold $70 \%$ ethanol and stored at $253 \mathrm{~K}$ overnight. Afterward, the cells were centrifuged, resuspended in $200 \mu \mathrm{L}$ of Muse ${ }^{\mathrm{TM}}$ Cell Cycle Reagent, and incubated for $30 \mathrm{~min}$ at room temperature 
in the dark. After staining, the cells were processed for cell cycle analysis using a Muse Cell Analyzer (Millipore, Burlington, MA, USA). The experiments were performed at least three times.

\subsubsection{Annexin V Binding Assay}

The PANC-1 cells were seeded in $3 \mathrm{~cm}$ Petri dishes (Nunc, Roskilde, Denmark) at a density of $0.25 \cdot 10^{6}$ cells/well and incubated at $310 \mathrm{~K}$ for $24 \mathrm{~h}$. The medium was then removed, and freshly prepared solutions of the tested nanocomposites, $\mathrm{Ag} / \mathrm{SiO}_{2}, \mathrm{Ag} / \mathrm{SiO}_{2} @ \mathrm{CMC}$, and $\mathrm{Ag} / \mathrm{SiO}_{2} @ \mathrm{AS}$, were added at a $30 \mathrm{mg} / \mathrm{L}$ concentration. After $48 \mathrm{~h}$, the assays were performed using an Annexin $\mathrm{V}$ and Dead Cell Kit (Millipore, Burlington, MA, USA) according to the manufacturer's instructions. Briefly, detached and adherent cells were collected and centrifuged at $500 \times g$ for $5 \mathrm{~min}$. Next, the resuspended cells were incubated with $100 \mu \mathrm{L}$ of Muse ${ }^{\mathrm{TM}}$ Annexin V \& Dead Cell Reagent for $20 \mathrm{~min}$ at room temperature in the dark. After staining, the events for life, early and late apoptotic cells were counted using a Muse Cell Analyzer (Millipore, Burlington, MA, USA). The experiments were performed at least three times.

\subsubsection{Immunoblotting}

The PANC- 1 cells were seeded in $3 \mathrm{~cm}$ Petri dishes (Nunc) at a density of $0.5 \cdot 10^{6}$ cells/well and incubated overnight. The next day, solutions of the nanocomposite $\mathrm{Ag} / \mathrm{SiO}_{2} @ \mathrm{CMC}(30 \mathrm{mg} / \mathrm{L})$ and DOX ( $5 \mu \mathrm{M}$ concentration) were added, and the cells were incubated for $24 \mathrm{~h}$. Cells were harvested via trypsinization and washed with cold PBS. Next, the cells were centrifuged and suspended in a RIPA buffer (Thermo Scientific, Waltham, MA, USA) containing a Halt Protease Inhibitor Cocktail (Thermo Scientific, Waltham, MA, USA), a Halt Phosphatase Inhibitor Cocktail (Thermo Scientific, Waltham, MA, USA) along with $0.5 \mathrm{M}$ EDTA and lysed for $20 \mathrm{~min}$ on ice. Then, the lysates were sonicated, centrifuged at 10,000 rpm for $10 \mathrm{~min}$ at $277 \mathrm{~K}$, and the supernatants were collected for further analysis. The protein concentration was determined using a Micro BCA ${ }^{\mathrm{TM}}$ Protein Assay Kit (Thermo Scientific, Waltham, MA, USA) according to the manufacturer's instructions. Equal amounts of the proteins $(20 \mu \mathrm{g})$ were electrophoresed on SDS-Page gels and transferred onto nitrocellulose membranes. The membranes were blocked in 5\% non-fat milk prepared in PBS containing 0.1\% Tween-20 (TPBS) for $1 \mathrm{~h}$. After blocking, the membranes were incubated with specific primary antibodies: p53, cyclin E1, heme oxygenase (HO-1), and GAPDH overnight at $277 \mathrm{~K}$, then washed and incubated with horseradish peroxidase (HRP)-conjugated secondary antibodies for $1 \mathrm{~h}$ at room temperature. All of the antibodies were purchased from Cell Signaling (Danvers, MA, USA) and were diluted 1:1000 in 5\% milk in TPBS. Finally, the membranes were washed and incubated with a SuperSignal ${ }^{\text {TM }}$ West Pico Chemiluminescent Substrate (Thermo Scientific). The chemiluminescence signals were captured using a ChemiDoc ${ }^{\mathrm{TM}}$ XRS+ System (Bio-Rad, Hercules, CA, USA). The experiments were performed at least three times.

\subsubsection{Statistical Analysis}

The results were expressed as the mean \pm standard deviation (SD) from at least three independent experiments. Statistical analysis of the ROS measurements was performed using the two-tailed Student's t-test. The statistical differences in the expression of proteins, the cell cycle's progression, and Annexin V binding assay were calculated using the one-way ANOVA with a Bonferroni post-hoc test. A p-value of 0.05 or less was considered to be statistically significant. GraphPad Prism v.7.0 software (GraphPad Software, San Diego, CA, USA) was used for the analysis.

\section{Results}

\subsection{Structural Analysis-XRD and Raman Studies}

The X-ray diffraction pattern of the initial silver-silica nanocomposite showed a combination of the signal that originated from the crystalline and amorphous phases. The main diffraction lines indicated silver oxide $\left(\mathrm{Ag}_{2} \mathrm{O}\right)$ with a cubic structure $(\mathrm{Pn}-3 \mathrm{~m})$. Less intense peaks were found that 
were derived from $\beta-\mathrm{Ag}_{2} \mathrm{CO}_{3}$ with a hexagonal structure (P31c) and $\mathrm{Ag}_{6} \mathrm{Si}_{2} \mathrm{O}_{7}$ with a monoclinic structure (P2/n). The very wide hump appeared at the $2 \theta$ range $15-27^{0}$ correspond to amorphous silica (Figure 2). A similar diffraction pattern was identified in the Ag/ $/ \mathrm{S}_{2} @ \mathrm{AS}$. The Rietveld refinement revealed comparable values for the same crystalline phases, and similar crystallite sizes were estimated for the most substantial peak for $\mathrm{Ag}_{2} \mathrm{O}$ in the $\left.\langle 111\rangle,<200\right\rangle$, and $<220>$ directions (Tables 1 and 2 ). Additionally, silver chloride $(\mathrm{AgCl})$ with a cubic structure $(\mathrm{Fm}-3 \mathrm{~m})$ was also detected (Figure 2). In turn, the $\mathrm{Ag} / \mathrm{SiO}_{2} @ \mathrm{CMC}$ sample was characterized by the presence of the silver chloride with large crystallites, which was found as the main phase due to a sharp and robust diffraction pattern (Figure 2 and Table 2). The low intense diffraction peaks highlighted a nanocrystalline metallic silver $\left(\mathrm{Ag}^{0}\right)$ with a cubic structure (Fm-3m). The absence of the diffraction peaks of $\mathrm{Ag}_{2} \mathrm{CO}_{3}$ and $\mathrm{Ag}_{6} \mathrm{Si}_{2} \mathrm{O}_{7}$ may have resulted from the detection limit or a very low amount of those phases in the composite.
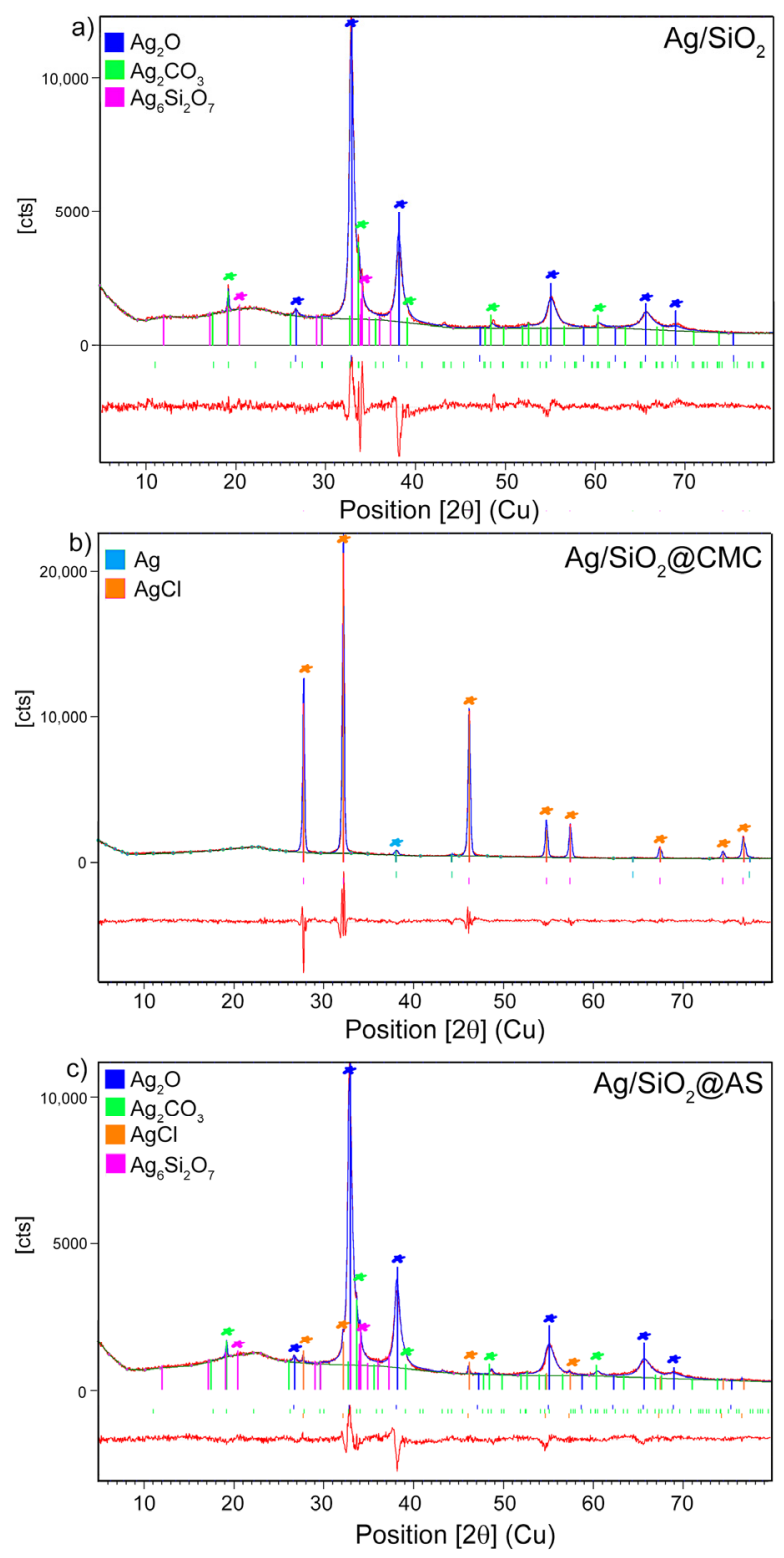

Figure 2. XRD pattern of (a) initial $\mathrm{Ag} / \mathrm{SiO}_{2}$ powder and modified systems by (b) carboxymethylcellulose: $\mathrm{Ag} / \mathrm{SiO}_{2} @ \mathrm{CMC}$ and (c) sodium alginate: $\mathrm{Ag} / \mathrm{SiO}_{2} @ \mathrm{AS}$ with the Rietveld refinement (red line). 
Table 1. The lattice parameters were determined from the XRD data and the analysis of the Rietveld refinement.

\begin{tabular}{|c|c|c|c|c|c|}
\hline $\begin{array}{c}\text { Phase } \\
\text { (Space Group) }\end{array}$ & $\begin{array}{c}\mathrm{Ag} \\
(\mathrm{Fm}-3 \mathrm{~m})\end{array}$ & $\begin{array}{c}\text { AgCl } \\
(\mathrm{Fm}-3 \mathrm{~m})\end{array}$ & $\begin{array}{c}\mathrm{Ag}_{2} \mathrm{O} \\
(\mathrm{Pn}-3 \mathrm{~m})\end{array}$ & \multicolumn{2}{|c|}{$\begin{array}{c}\beta-\mathrm{Ag}_{2} \mathrm{CO}_{3} \\
\left(\mathrm{P3}_{1} \mathrm{c}\right)\end{array}$} \\
\hline Lattice Parameters & $\mathbf{a}_{0}[\AA]$ & $\mathbf{a}_{0}[\AA]$ & $\mathbf{a}_{0}[\AA]$ & $\mathbf{a}_{0}[\AA ̊]$ & $c_{0}[\AA ̊]$ \\
\hline $\mathrm{Ag} / \mathrm{SiO}_{2}$ & - & - & $4.710(9)$ & $9.208(4)$ & $6.490(7)$ \\
\hline $\mathrm{Ag} / \mathrm{SiO}_{2} @ \mathrm{CMC}$ & $4.085(5)$ & $5.550(6)$ & - & - & - \\
\hline $\mathrm{Ag} / \mathrm{SiO}_{2} @ \mathrm{AS}$ & - & $5.554(9)$ & $4.714(4)$ & $9.202(2)$ & $6.485(2)$ \\
\hline
\end{tabular}

Table 2. The crystallite sizes were estimated based on the XRD data.

\begin{tabular}{|c|c|c|c|c|c|}
\hline \multicolumn{2}{|c|}{$\mathrm{Ag}_{2} \mathrm{O}\left(\mathrm{AgSiO}_{2}\right)$} & \multicolumn{2}{|c|}{$\mathrm{AgCl}\left(\mathrm{AgSiO}_{2} @ \mathrm{CMC}\right)$} & \multicolumn{2}{|c|}{$\mathrm{Ag}_{2} \mathrm{O}\left(\mathrm{AgSiO}_{2} @ \mathrm{AS}\right)$} \\
\hline Direction & Crystallite Size [Å] & Direction & Crystallite Size [Å] & Direction & Crystallite Size [̊̊] \\
\hline$<111>$ & 172 & $<111>$ & 901 & $<111>$ & 168 \\
\hline$<200>$ & 135 & $<200>$ & 747 & $<200>$ & 132 \\
\hline$<220>$ & 82 & $<220>$ & 674 & $<220>$ & 81 \\
\hline
\end{tabular}

The Raman spectrum of pure silica is usually divided into two regions of which the first (1) range includes bands of the medium-range order silica superstructures $\left(200-800 \mathrm{~cm}^{-1}\right)$ and the second (2) refers to the silicon-oxygen tetrahedral $Q^{n}(\mathrm{n}=0-4$ and stands for the amount of bridging oxygen per $\mathrm{SiO}_{4}$ tetrahedron) modes $\left(800-1250 \mathrm{~cm}^{-1}\right)$ [56,57].

The band arrangement of the reference pure silica in the region (1) aligns with the spectra of the $\mathrm{Ag} / \mathrm{SiO}_{2}$ and $\mathrm{Ag} / \mathrm{SiO}_{2} @ \mathrm{AS}$, while the additional band that is located in the vicinity of $229 \mathrm{~cm}^{-1}$ correlates with an overlapping signal that originated from $\mathrm{Ag}-\mathrm{O}$ vibration within the $\mathrm{Ag}_{2} \mathrm{O}$ group $[44,58]$ and the Si-O-Si modes (Figure 3). Similar band positions found for the reference silica indicate a low chemical interaction of silver on a silica network [59-61]. The narrow bands between $350-470 \mathrm{~cm}^{-1}$ correspond to the n-membered rings ( $\mathrm{n}>5$ ), the deformational modes of the silanol ( $\mathrm{Si}-\mathrm{OH}$ ) group [57,62], or structural point defects (Figure 3). The most intense bands' position and intensity are centered at $243,271 \mathrm{~cm}^{-1}$ in the $\mathrm{Ag} / \mathrm{SiO}_{2} @ \mathrm{CMC}$ spectrum, suggest an atypical molecular configuration in which the chloride ligands probably surround the $\mathrm{Ag}^{+}$-ions octahedral coordination [63]. This molecular arrangement implies the activation of powerful stretching vibrations of the bridging $\mathrm{Ag}-\mathrm{Cl}$ modes as well as the terminal chlorine atoms, respectively, for the lower and higher Raman frequencies (Figure 3). Similar to previous studies, the existence of unsaturated-Si-O* bonds favors the formation of the silanol group [57,62].

The bands of the region (2) are a marker for determining the quality of a three-dimensional $\mathrm{SiO}_{2}$ network. In this context, the Raman spectra of the $\mathrm{Ag} / \mathrm{SiO} \mathrm{O}_{2}$ and $\mathrm{Ag} / \mathrm{SiO} \mathrm{O}_{2} @ \mathrm{AS}$ samples indicate a band arrangement similar to the band number and intensity, while their position differs slightly. Five bands around at $867,914,984,1076$, and $1146 \mathrm{~cm}^{-1}$ (reference $\mathrm{Ag} / \mathrm{SiO}_{2}$ spectrum) and at 874, 939, 1009, 1085, and $1155 \mathrm{~cm}^{-1}\left(\mathrm{Ag} / \mathrm{SiO}_{2} @ \mathrm{AS}\right)$ indicated the strong depolymerization of silica network correlating with the $Q^{0}, Q^{1}, Q^{2}, Q^{3}$, and $Q^{4}$ units [64] of $\mathrm{SiO}_{4}$ tetrahedra (Figure 3) [56,65]. A low intense band about $800 \mathrm{~cm}^{-1}$ in both samples results from Si vibration trapped in an oxygen cage $[56,64]$. In turn, two low intense bands at 870 and $1061 \mathrm{~cm}^{-1}\left(\mathrm{Ag} / \mathrm{SiO}_{2} @ \mathrm{CMC}\right)$ correspond to the $Q^{0}$ and $Q^{3} / Q^{4}$ units, wherein its position and intensity relate to the reference silica and may suggest the low impact of $\mathrm{AgCl}$ clusters on depolymerization of the silica network. The bands above $1400 \mathrm{~cm}^{-1}$, which had relatively high linewidths, corresponded to the organic polymer residues that had been dropped into the colloidal suspension during the chemical synthesis. 


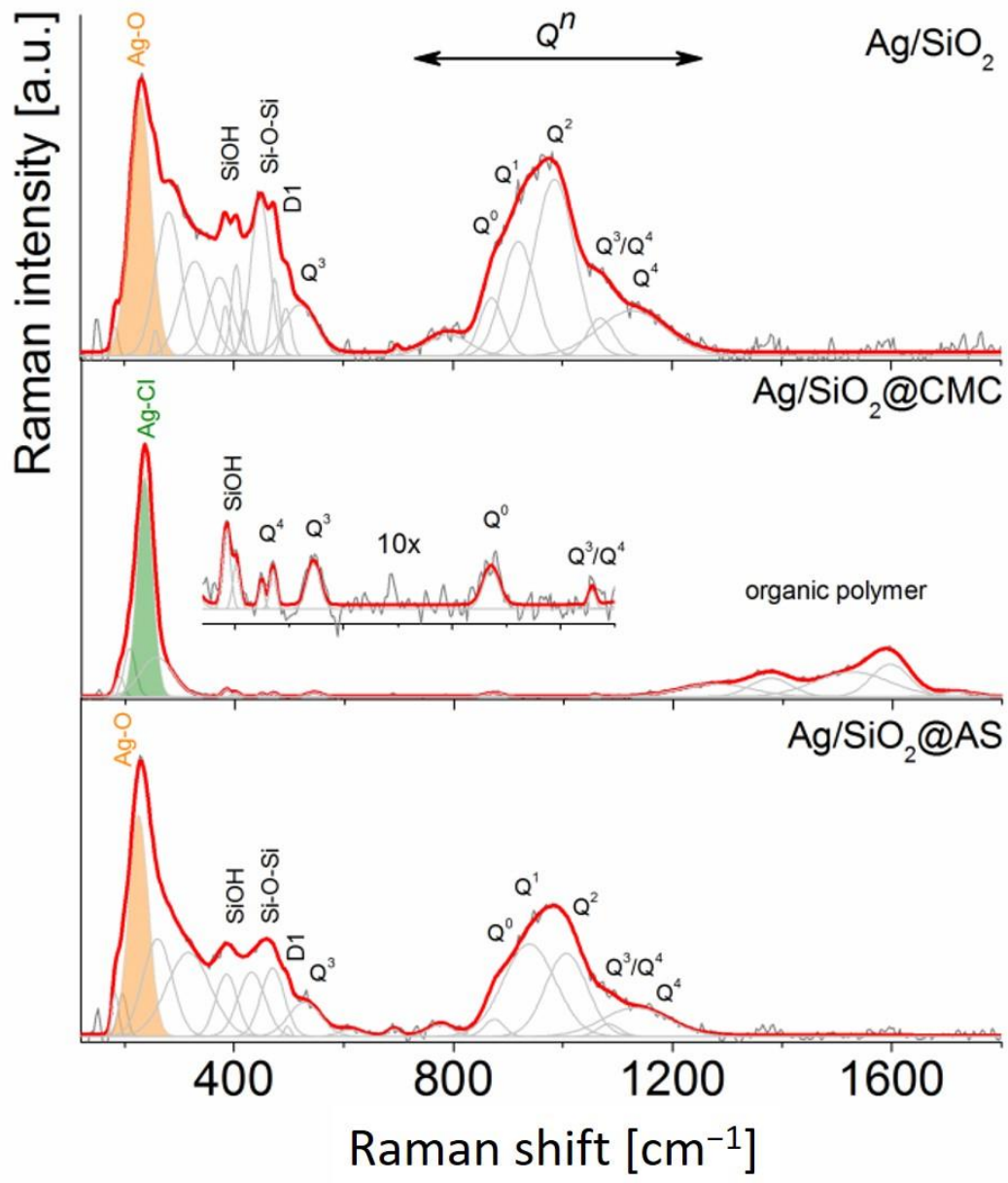

Figure 3. The Raman spectra of the silver-silica $\left(\mathrm{Ag} / \mathrm{SiO}_{2}\right)$ and modified nanocomposites through carboxymethylcellulose $\left(\mathrm{Ag} / \mathrm{SiO}_{2} @ \mathrm{CMC}\right)$ and sodium alginate $\left(\mathrm{Ag} / \mathrm{SiO}_{2} @ \mathrm{AS}\right)$ were in the $120-1800$ $\mathrm{cm}^{-1}$ region. Additionally, to better illustrate the silica matrix signal, the $350-1100 \mathrm{~cm}^{-1}$ region in $\mathrm{Ag} / \mathrm{SiO}_{2} @ \mathrm{CMC}$ was magnified $10 \times$. Each spectrum was fitted using the Voigt function and a minimum number of components.

\subsection{Microscopic Observations vs the Chemical Composition}

The SEM observations combined with the EDS analysis revealed the irregular size of the silica particles from $(21.6 \pm 1.2) \mu \mathrm{m}$ to $(497.4 \pm 2.3) \mu \mathrm{m}$ (gray areas in Figure 4$)$ and the silver had dispersed with much more homogeneity on the silica carrier (brighter areas in Figure 4a-c). The TEM analysis showed that at the nanoscale, the silver was spread heterogeneously in the $\mathrm{Ag} / \mathrm{SiO}_{2}$ within a silica matrix with an average particle size that was estimated based on a Gaussian function and that was approximated as $\mathrm{d}=(7.8 \pm 0.3) \mathrm{nm}$ (Figure $5 \mathrm{a})$. The silver nanoparticles had spherical shapes for $\mathrm{Ag} / \mathrm{SiO}_{2} @ \mathrm{CMC}$ and were also more diversified and trended toward spheroidal- and irregular-shaped structures for $\mathrm{Ag} / \mathrm{SiO}_{2} @ \mathrm{AS}$ (Figure $5 \mathrm{~b}, \mathrm{c}$ ). Hence, determining their size was difficult, and this resulted in estimating the approximate values as $\mathrm{d}=(44.1 \pm 2.3) \mathrm{nm}$ for $\mathrm{Ag} / \mathrm{SiO}_{2} @ \mathrm{CMC}$ and $\mathrm{d}=(6.6 \pm 0.7)$ $\mathrm{nm}$ for $\mathrm{Ag} / \mathrm{SiO}_{2} @ \mathrm{AS}$ (Figure $5 \mathrm{~b}, \mathrm{c}$ ). The diffraction pattern for all of the structures determined from the selected area electron diffraction (SAED) and XRD data coincided (Table 3). Silver was found in two valence states $\left(\mathrm{Ag}^{+}\right.$and $\left.\mathrm{Ag}^{2+}\right)$ in $\mathrm{Ag} / \mathrm{SiO}{ }_{2}$ and $\mathrm{Ag} / \mathrm{SiO}_{2} @ \mathrm{AS}$, while in $\mathrm{Ag} / \mathrm{SiO}_{2} @ \mathrm{CMC}$, it was in a metallic $\mathrm{Ag}^{0}$ or silver connected to chlorine. It is worth noting that the metallic and oxide silver structural parameters were similar to other silver-silica composites, which were presented in our earlier works $[44,46]$. 

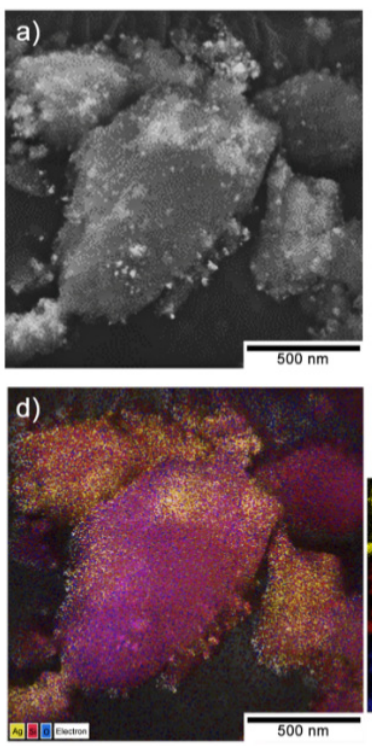
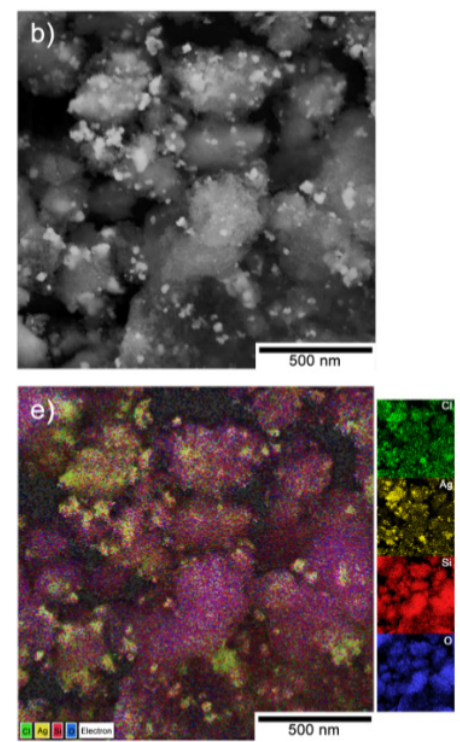
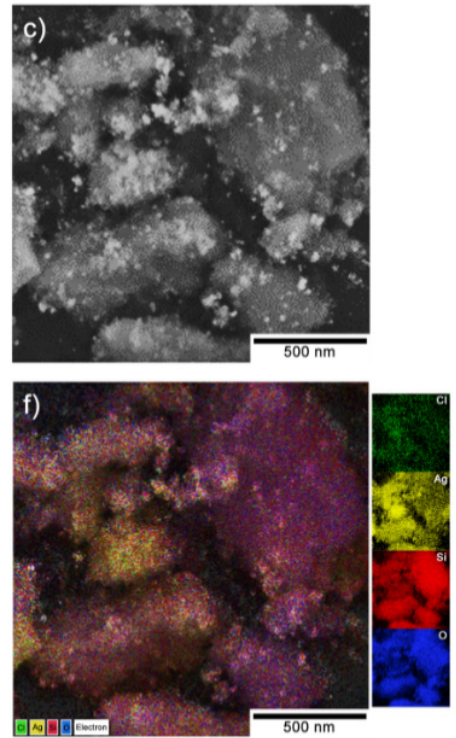

Figure 4. Backscattered electron (BSE)-SEM (a-c) images present the morphology of (a) $\mathrm{Ag} / \mathrm{SiO}_{2}$, (b) $\mathrm{Ag} / \mathrm{SiO}_{2} @ \mathrm{CMC}$, (c) $\mathrm{Ag} / \mathrm{SiO}_{2} @ \mathrm{AS}$ and the SEM-energy dispersive spectrometer (EDS) chemical composition maps of the (d) $\mathrm{Ag} / \mathrm{SiO}_{2}$, (e) $\mathrm{Ag} / \mathrm{SiO}_{2} @ \mathrm{CMC}$, and (f) $\mathrm{Ag} / \mathrm{SiO}_{2} @ \mathrm{AS}$ nanocomposites and their derivatives. The small insets highlight the individual elemental distribution maps of Ag (yellow), $\mathrm{Si}$ (red), $\mathrm{O}$ (blue), and $\mathrm{Cl}$ (green) from the EDS. CMC means carboxymethylcellulose, while AS refers to sodium alginate.

a)

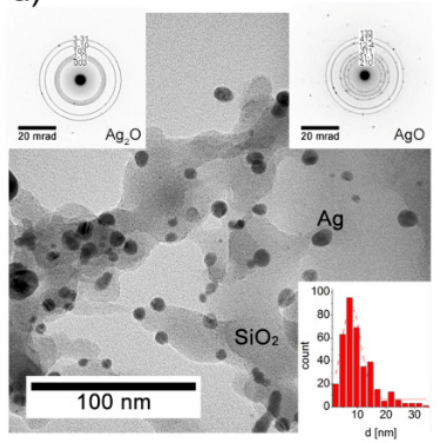

b)

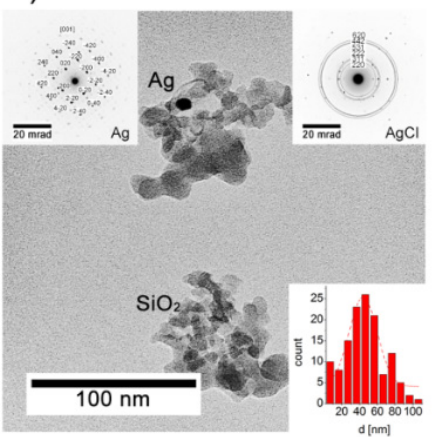

c)

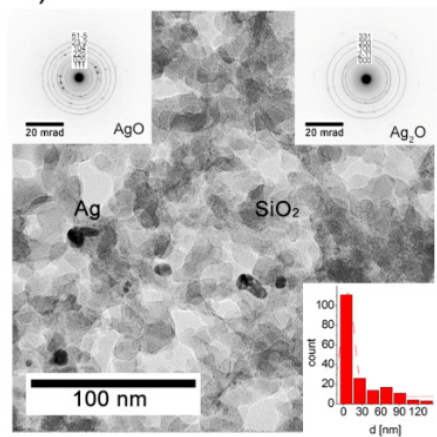

Figure 5. High resolution transmision electron microscopy (HRTEM) images of (a) the pure silver-silica nanocomposite and the chemically modified silver-silica derivatives; (b) $\mathrm{Ag} / \mathrm{SiO}_{2} @ \mathrm{CMC}$ and (c) $\mathrm{Ag} / \mathrm{SiO}_{2} @ \mathrm{AS}$ with an inset showing the selected area electron diffraction (SAED) patterns for $\mathrm{Ag}$ and the size distribution of Ag fitted by the Gaussian function.

Table 3. Crystallographic data (lattice parameters, system, and space group) of the initial and modified silver-silica nanocomposites that were obtained based on the TEM + SAED data.

\begin{tabular}{ccccccc}
\hline \multirow{2}{*}{ Element } & \multicolumn{2}{c}{$\mathrm{Ag} / \mathrm{SiO}_{2}$} & \multicolumn{2}{c}{$\mathrm{Ag} / \mathrm{SiO}_{\mathbf{2}} @ \mathbf{C M C}$} & \multicolumn{2}{c}{$\mathrm{Ag} / \mathrm{SiO}_{2} @ \mathrm{AS}$} \\
\cline { 2 - 7 } & $\mathbf{A g O}$ & $\mathbf{A g}_{2} \mathbf{O}$ & $\mathbf{A g}$ & $\mathbf{A g C l}$ & $\mathbf{A g O}$ & $\mathbf{A g}_{2} \mathbf{O}$ \\
\hline $\mathrm{a}_{0}[\AA]$ & 5.8517 & 3.072 & 4.0855 & 5.5463 & 5.8517 & 3.072 \\
\hline $\mathrm{b}_{0}[\AA]$ & 3.4674 & 3.072 & 4.0855 & 5.5463 & 3.4674 & 3.072 \\
\hline $\mathrm{c}_{0}[\AA]$ & 5.4838 & 4.941 & 4.0855 & 5.5463 & 5.4838 & 4.941 \\
\hline system & monoclinic & trigonal & cubic & cubic & monoclinic & trigonal \\
\hline space group & $\mathrm{P} 21 / \mathrm{c}$ & $\mathrm{P}-3 \mathrm{~m} 1$ & Fm-3m & Fm-3m & P21/c & P-3m1 \\
\hline
\end{tabular}


The elemental distribution maps of $\mathrm{Si}, \mathrm{O}$, and $\mathrm{Ag}$, as well as chlorine as an impurity that originated from the presence of additives in the organic polymers in the two modified silver-silica systems, were analyzed more in detail (Figure 4). According to these, the silver in the entire volume of the reference and sodium-alginate-modified composites was homogenously dispersed. In turn, it tended to agglomerate into a spherical shape in $\mathrm{Ag} / \mathrm{SiO}_{2} @ \mathrm{CMC}$ (Figure 4d-f). Moreover, the chlorine distribution map in the modified $\mathrm{Ag} / \mathrm{SiO}_{2}$ compounds indicated a correlation between chlorine and silver due to the formation of the $\mathrm{AgCl}$ systems previously identified using the diffraction method (Figure 2). More precise information about elemental composition, chemical and electronic states considering the surface was obtained with X-ray photoemission spectroscopy (XPS) (Figures 6 and 7). In this context, the $\mathrm{O} 1 \mathrm{~s}$ line in the reference sample was deconvoluted into three components $(530.35 \mathrm{eV}$, $531.3 \mathrm{eV}, 533.1 \mathrm{eV}$ ), which were ascribed to the silver oxides. In the modified samples, the most intense components at binding energies 532.2 and $532.9 \mathrm{eV}$ were assigned to $\mathrm{SiO}_{2}$, while the other states of oxygen denoted as $\mathrm{SiO}_{2-x}, \mathrm{AgO}$, and $\mathrm{O} / \mathrm{Ag}$ with peaks at 531.2, 530.9, and $529.3 \mathrm{eV}$. The Si 2p core lines revealed a non-stoichiometric $\mathrm{SiO}_{x}(101.2 \mathrm{eV})$ and a stoichiometric $\mathrm{SiO}_{2}(103.2 \mathrm{eV})$ silica in each of the studied composites. Other peaks found at 100.2, 102.4, and $104.3 \mathrm{eV}$ were correlated with the $\mathrm{SiC}\left(\mathrm{Ag} / \mathrm{SiO}_{2} @ \mathrm{AS}\right), \mathrm{SiO}_{2-x}\left(\mathrm{Ag} / \mathrm{SiO}_{2} @ \mathrm{CMC}\right)$, and $\mathrm{SiO} / \mathrm{SiOH}\left(\mathrm{Ag} / \mathrm{SiO}_{2}\right)$ [66]. An interpretation of the $\mathrm{Ag} 3 \mathrm{~d}$ lines indicated silver in its metallic state at the surface for all of the samples due to the photoelectron lines at the binding energies located in the interval from 368.3 to $368.6 \mathrm{eV}$ (Figure 3). Other lines at 366.3 and $369.2 \mathrm{eV}\left(\mathrm{Ag} / \mathrm{SiO}_{2}\right)$ as well as at $366.1 \mathrm{eV}\left(\mathrm{Ag} / \mathrm{SiO}_{2} @ \mathrm{CMC}\right)$ were derived from the splitting of the $3 \mathrm{~d}$ doublet equal $6.0 \mathrm{eV}$ [67], was linked to the formation of the ionic silver cluster on the surface of the silver nanoparticles immediately after the synthesis [68]. The additional lines, which were located at $367.8\left(\mathrm{Ag} / \mathrm{SiO}_{2} @ \mathrm{CMC}\right)$ and $367.6 \mathrm{eV}\left(\mathrm{Ag} / \mathrm{SiO}_{2} @ \mathrm{AS}\right)$, resulted from the $\mathrm{AgCl}$ moieties and the formation of $\mathrm{AgO}$ [69], respectively. In turn, one of the components within the $\mathrm{Cl} 2 \mathrm{p}$ core level (Ag/ $\left.\mathrm{SiO}_{2} @ \mathrm{CMC}\right)$ with binding energy equal to $198.4 \mathrm{eV}$ was ascribed to the $\mathrm{AgCl}$ cluster, while the nature of the other components at 197.4 and $201.8 \mathrm{eV}$ were derived from the chlorine ions and chlorine, which are covalently bonded with the carbon (Figure 7). When the bulk and surface chemical composition were compared, the macroscopically silver content was estimated as $12.6 \%$, $6.8 \%$, and $7.9 \%$, while for the surface analysis, it was $1.6 \%, 0.6 \%$, and $1.8 \%$, respectively, for $\mathrm{Ag} / \mathrm{SiO}_{2}$, $\mathrm{Ag} / \mathrm{SiO}_{2} @ \mathrm{CMC}$, and $\mathrm{Ag} / \mathrm{SiO}_{2} @ \mathrm{AS}$. The chlorine content was $0.85 \%$ in $\mathrm{Ag} / \mathrm{SiO}_{2} @ \mathrm{CMC}$, while during the bulk analysis, it was $3.4 \%$ and there was only a trace amount of $0.2 \%$ in $\mathrm{Ag} / \mathrm{SiO}_{2} @ \mathrm{CMC}$ and $\mathrm{Ag} / \mathrm{SiO}_{2} @ \mathrm{AS}$, respectively (Table 4). It is worth noting that all of the studied nanocomposites' surface was carbon contaminated and had an atomic concentration that ranged from $8.4 \%$ to $11.1 \%$ (Table 4 ). Moreover, as a result of the fitting analysis, the $C$ 1s core-level spectra indicated $C-C, C-O, C=O$, and $\mathrm{O}-\mathrm{C}=\mathrm{O}$ bonds [70].

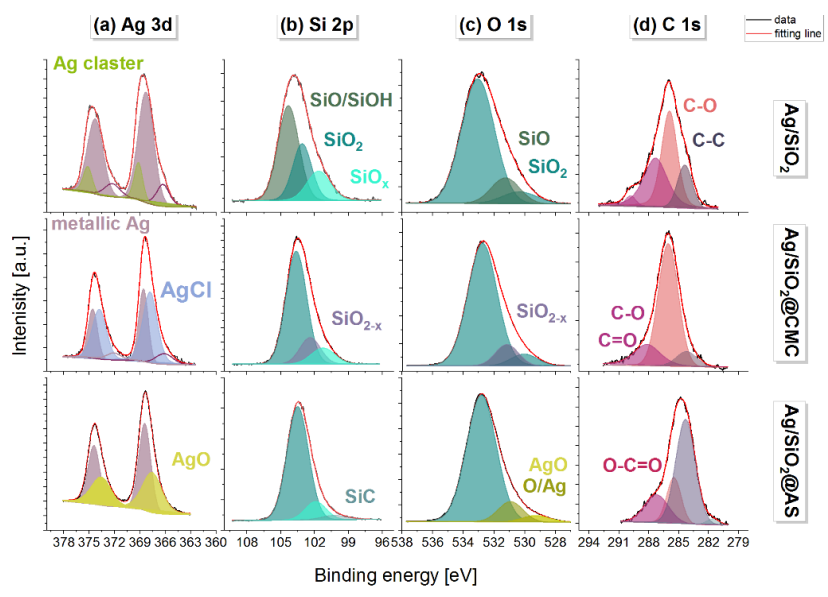

Figure 6. The XPS spectra of (a) Ag 3d, (b) Si 2p, (c) O 1s, and (d) the C 1s core levels with the fitting result. The individual colors on the specific lines' core levels refer to the individual chemical surroundings linked to the silver, silica, oxygen, and carbon. 


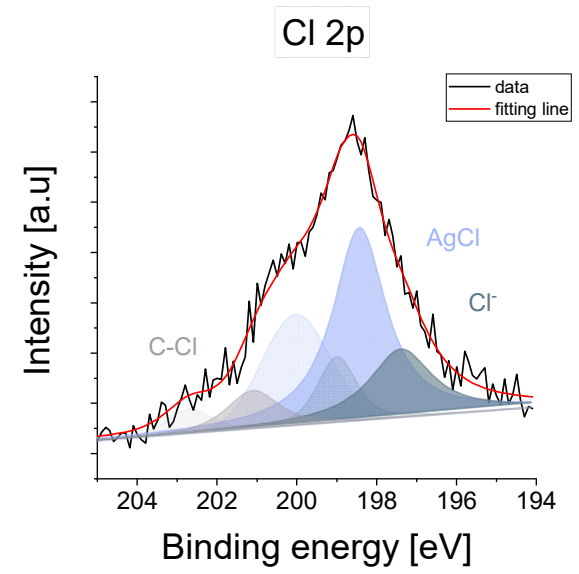

Figure 7. The XPS spectrum of the $\mathrm{Cl} 2 \mathrm{p}$ core level with the result of the fitting for $\mathrm{Ag} / \mathrm{SiO}_{2} @ \mathrm{CMC}$.

Table 4. The average atomic element concentration for the initial and modified silver-silica nanocomposites was estimated for the bulk (SEM-EDS) and surface (XPS). The data in the parentheses refer to the standard deviation data that was obtained based on the measurements of five different points.

\begin{tabular}{|c|c|c|c|c|c|c|}
\hline \multirow{2}{*}{ El. } & EDS & XPS & EDS & XPS & EDS & XPS \\
\hline & \multicolumn{2}{|c|}{$\mathrm{Ag} / \mathrm{SiO}_{2}$ [at.\%] } & \multicolumn{2}{|c|}{$\mathrm{Ag} / \mathrm{SiO}_{2} @ \mathrm{CMC}$ [at.\%] } & \multicolumn{2}{|c|}{$\mathrm{Ag} / \mathrm{SiO}_{2} @ \mathrm{AS}$ [at.\% } \\
\hline $\mathrm{O}$ & $63.3(3.0)$ & 59.1 & $69.6(1.6)$ & 59.4 & $71.1(0.7)$ & 58.1 \\
\hline $\mathrm{Si}$ & $24.1(1.8)$ & 28.8 & $20.1(0.5)$ & 30.7 & $20.9(0.9)$ & 28.9 \\
\hline $\mathrm{Cl}$ & - & - & $3.4(0.9)$ & 0.9 & $0.2(0.1)$ & - \\
\hline $\mathrm{Ag}$ & $12.6(2.2)$ & 1.6 & $6.8(1.1)$ & 0.6 & $7.9(1.3)$ & 1.8 \\
\hline$C$ & - & 10.5 & - & 8.4 & - & 11.2 \\
\hline
\end{tabular}

\subsection{Antimicrobial Properties}

The 'spot test' was used to determine the silver-silica nanocomposites' antimicrobial properties and reference silver nitrate. The results are expressed as the minimum biocidal concentration (MBC), i.e., the lowest concentration $(\mathrm{mg} / \mathrm{L})$ that inhibited microbial growth (Figure 8, Table 5). The results showed that the silver-silica nanocomposites were able to inhibit microbial growth at the tested concentrations. The $\mathrm{MBC}$ values that were obtained for the reference $\mathrm{Ag} / \mathrm{SiO} \mathrm{O}_{2}$ were ten-fold higher relative to the $\mathrm{Ag}^{+}$-ions for the Gram-negative bacteria and were at the same level for the Gram-positive strains. The results were similar for the $\mathrm{Ag} / \mathrm{SiO}_{2} @ \mathrm{AS}$ nanocomposite, except for L. plantarum, which had an $\mathrm{MBC}$ slightly higher than the initial sample. There were also some differences for $\mathrm{Ag} / \mathrm{SiO} \mathrm{O}_{2} \mathrm{CMC}$ for which the slightly lower silver content (6.8\%/0.6\%) translated into ten-fold lower toxicity for P. aeruginosa and S. aureus than other systems. Moreover, the toxicity pattern of the tested nanocomposites against yeast had lower antifungal properties but still ten-fold higher than the reference $\mathrm{AgNO}_{3}$ (Figure 8, Table 5).

Table 5. Minimum biocidal concentration (MBC) for $\mathrm{Ag} / \mathrm{SiO}_{2}$ and its derivatives after a $24 \mathrm{~h}$ exposure in deionized water at $297 \mathrm{~K}$ on the bacterial and yeast strains in nominal concentrations from $0.01 \mathrm{up}$ to $1000 \mathrm{mg} / \mathrm{L}$. The results were combined with the reference $\mathrm{Ag}^{+}$-ions $\left(\mathrm{AgNO}_{3}\right)$. Different colors indicate different $\mathrm{MBC}$ values. All of the values were obtained based on experiments in three replicates.

\begin{tabular}{cccccccc}
\hline \multirow{2}{*}{ Nanocomposites } & \multicolumn{2}{c}{ Gram-Negative Bacteria } & \multicolumn{2}{c}{ Gram-Positive Bacteria } & \multicolumn{2}{c}{ Yeast } \\
\cline { 2 - 8 } & E. coli & P. aeruginosa & L. plantarum & S. aureus & C. albicans & S. cerevisiae \\
\hline $\mathrm{AgSiO}_{2}$ & 10 & 10 & 0.1 & 10 & 1000 & 1000 \\
\hline $\mathrm{AgSiO}_{2} @ \mathrm{CMC}$ & 10 & 100 & 1 & 10 & 1000 & 1000 \\
\hline $\mathrm{AgSiO}_{2} @ \mathrm{AS}$ & 10 & 10 & 0.1 & 10 & 100 & 100 \\
\hline $\mathrm{AgNO}_{3}$ & 1 & 1 & & &
\end{tabular}




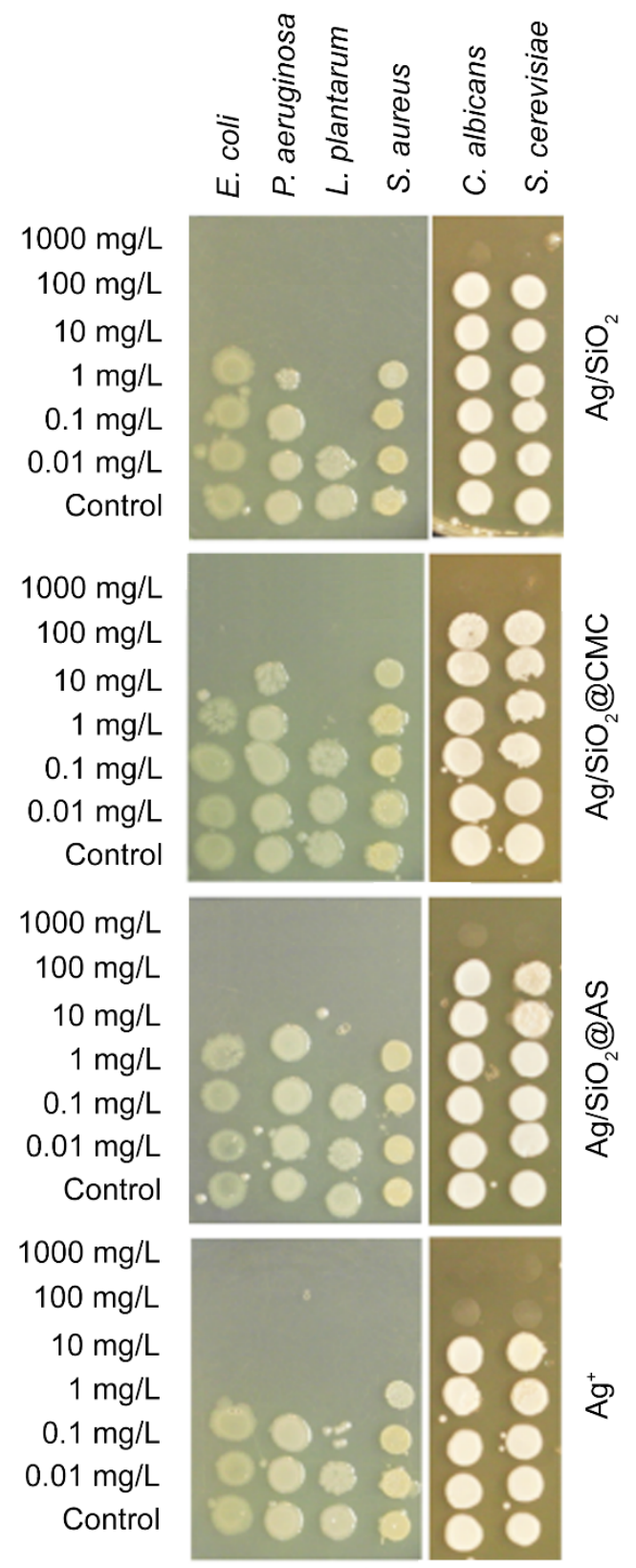

Figure 8. The ability of the Gram-negative (Escherichia coli, Pseudomonas aeruginosa), Gram-positive bacteria (Lactobacillus plantarum, Staphylococcus aureus) and yeast strains (Candida albicans, Saccharomyces cerevisiae) to form a colony after a $24 \mathrm{~h}$ exposure to the $\mathrm{Ag} / \mathrm{SiO}_{2}, \mathrm{Ag} / \mathrm{SiO}_{2} @ \mathrm{CMC}, \mathrm{Ag} / \mathrm{SiO} \mathrm{O}_{2} @ \mathrm{AS}$, and $\mathrm{Ag}^{+}$-ions (reference). After exposure, the cells $(5 \mu \mathrm{L})$ were transferred onto a toxicant-free agarized growth medium. The lowest concentration $(\mathrm{mg} / \mathrm{L})$, providing total microbial growth inhibition was considered minimum biocidal concentration (MBC).

\subsection{Anticancer Studies}

The reference and modified silver-silica nanocomposites were tested against different cancer cell lines: colon (HCT 116), breast (MCF-7), glioblastoma (U-251), and pancreatic (PANC-1), which represent the most common and aggressive tumors. The anticancer activity was evaluated in vitro based on an MTS assay (Table 6). According to this analysis, all of the investigated nanomaterials had excellent activity against all of the cancer cell lines. The highest activity was observed for MCF-7, which had an $\mathrm{IC}_{50}$ value of $11 \mathrm{mg} / \mathrm{L}$ for $\mathrm{Ag} / \mathrm{SiO}_{2} @ \mathrm{AS}$. In general, there were no significant differences 
between the tested nanocomposites for these cell lines. However, more significant differences were detected for PANC-1, which also expressed a good susceptibility.

In the next step, the compound's effect was tested based on the cell cycle and cell death induction. Here, there was a significant increase in the cell population in the $G_{2} / M$ phase for all compounds, which indicated the cell cycle inhibition in the phases above (Figure 9a). Furthermore, an experiment that enabled the type of cell death to be determined showed an increase of the apoptotic PANC-1 cell fraction after $48 \mathrm{~h}$ of cell treatment with all of the investigated nanocomposites. Here, the modified silver-silica nanocomposites had the most significant effect, i.e., $~ 50 \%$ increase in the number of apoptotic cells compared to the control. Further, a time-dependent kinetic experiment showed a growing trend in the ROS generation for the most cytotoxic agent $\left(\mathrm{Ag} / \mathrm{SiO}_{2} @ \mathrm{CMC}\right)$ (Figure 9c). An examination of the proteins using the Western Blot test confirmed the previous results. Here, several targets linked to the cell cycle inhibition, apoptosis, and ROS generation were investigated. It was found that $\mathrm{Ag} / \mathrm{SiO}_{2} @ \mathrm{CMC}$ caused the upregulation of the HO-1 protein without a significant impact on the p53 and cyclin E proteins.

a)

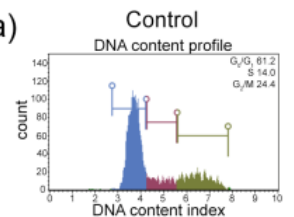

$\mathrm{Ag} / \mathrm{SiO}_{2} @ \mathrm{CMC}$
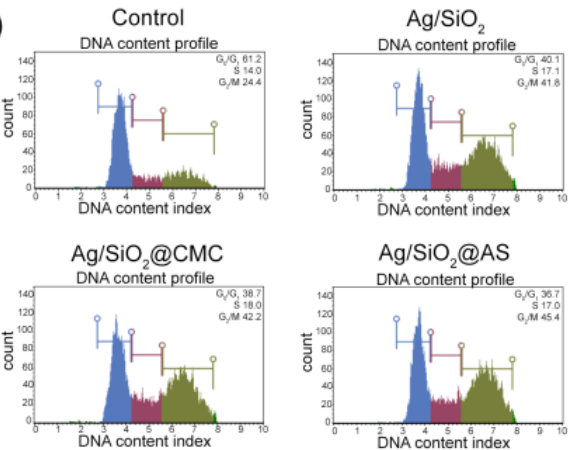

$\mathrm{Ag} / \mathrm{SiO} @ \mathrm{QAS}$
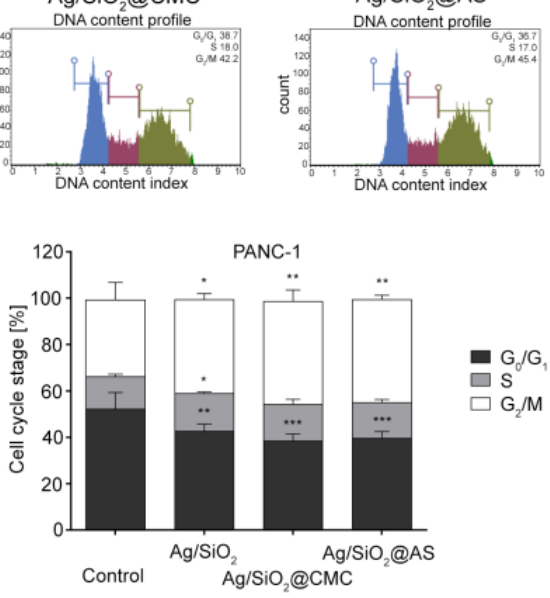

b)

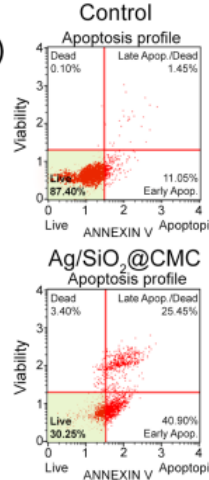

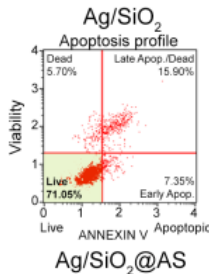

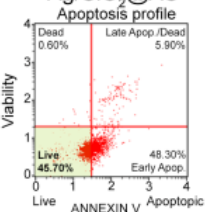

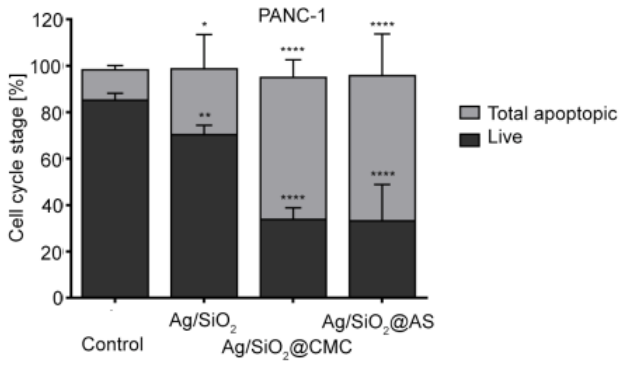

c)
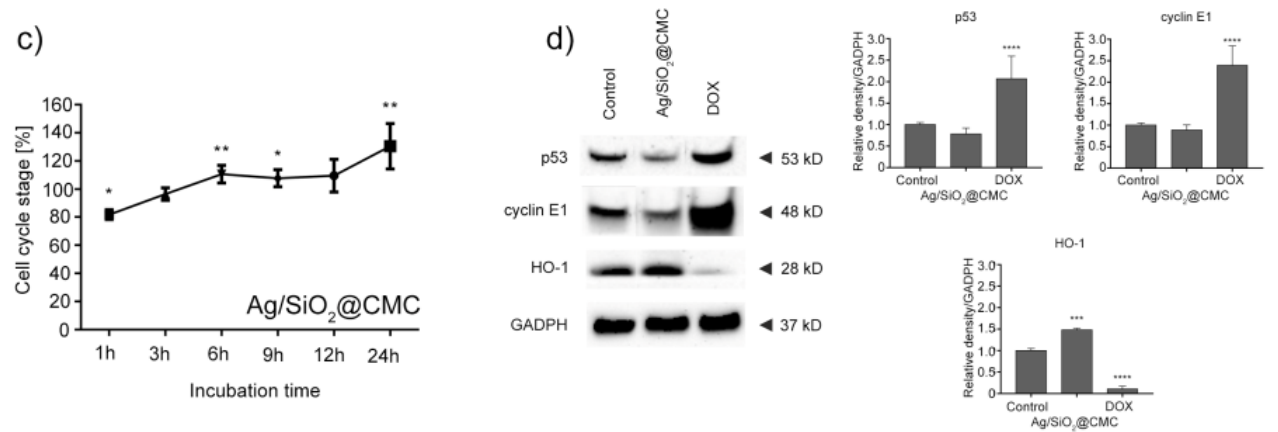

Figure 9. Impact of the tested nanocomposites at a $30 \mathrm{mg} / \mathrm{L}$ concentration on regulating the cell cycle (a) and inducing apoptosis (b) in the PANC-1 cells. Effect of the tested $\mathrm{Ag} / \mathrm{SiO}_{2} @ \mathrm{CMC}$ nanocomposite on the level of reactive oxygen species (ROS) in the PANC-1 cells. Data normalized to the untreated cells (control) (c). Impact of $\mathrm{Ag} / \mathrm{SiO}_{2} @ \mathrm{CMC}$ on the expression of the p53, cyclin E1, and HO-1 proteins in the PANC-1 cells. The densitometric analysis of these proteins was normalized to GADPH (d). The 
results from all experiments are shown as the mean \pm standard deviation (SD) of three independent measurements. Any statistical differences from the cell cycle, apoptosis, and immunoblotting experiments were analyzed using a one-way ANOVA with Bonferroni's post-hoc test. Data from ROS measurements were analyzed using the Student's $t$-test. Statistical significance: ${ }^{*} p<0.05,{ }^{* *} p<$ $0.01,{ }^{* * *} p<0.001,{ }^{* * * *} p<0.0001$ compared to the control group.

Table 6. Anti-proliferative activity ( $\mathrm{IC}_{50}$ values) of the tested nanocomposites against different human cancer cells.

\begin{tabular}{ccccc}
\hline \multirow{2}{*}{ Nanocomposite } & \multicolumn{4}{c}{ IC $_{\mathbf{5 0}}$ Values [mg/L] } \\
\cline { 2 - 5 } & HCT116 & MCF-7 & U-251 & PANC-1 \\
\hline $\mathrm{Ag} / \mathrm{SiO}_{2}$ & $24.0 \pm 9.3$ & $13.7 \pm 1.6$ & $34.2 \pm 8.5$ & $21.0 \pm 2$ \\
\hline $\mathrm{Ag} / \mathrm{SiO}_{2} @ \mathrm{CMC}$ & $24.2 \pm 2.4$ & $16.1 \pm 4.7$ & $38.7 \pm 4.3$ & $12.6 \pm 6.0$ \\
\hline $\mathrm{Ag} / \mathrm{SiO}_{2} @ \mathrm{AS}$ & $24.0 \pm 6.3$ & $11.1 \pm 2.0$ & $30.1 \pm 5.2$ & $19.7 \pm 7.5$ \\
\hline
\end{tabular}

\section{Discussion}

In recent years, much research has been focused on rapidly developing new kinds of nanomaterials with different target applications, e.g., photocatalytic or biological. These are usually dedicated to only one type of application. Therefore, the presented studies were focused on developing a new class of biologically active systems. This goal was achieved by (i) combining metal nanoparticles with an inorganic matrix or (ii) combining metal nanostructures with organic saccharide-derivatives (carboxymethylcellulose, sodium alginate, etc.). Despite the advantages and disadvantages of nanocomposites, the hybrid structures in the assumption ought to increase metallic silver stability. They also extend the effect of their action at a reduced concentration and intensify the entire system's biological properties. Hence, the research focused on reducing the negative effects of the simple silver-silica system and its derivatives. To do this, the physicochemical studies were correlated to the impact of the newly synthesized materials on bacteria, fungi, and cancer cells in an attempt to explain the potential mechanism of cell death.

An inorganic silver-silica nanocomposite and two organic-inorganic systems that had been encapsulated by sodium alginate and carboxymethylcellulose were prepared. The SEM and TEM studies illustrated heterogeneously distributed spherical nanoparticles. The EDS and XPS highlighted that they were in the form of metallic silver and silver oxides. Their sizes were estimated to be less than $10 \mathrm{~nm}$ in the silica network $\left(\mathrm{Ag} / \mathrm{SiO}_{2}, \mathrm{Ag} / \mathrm{SiO}_{2} @ \mathrm{AS}\right)$. In turn, spherical silver nanoparticles (Ag NPs) in the form of metallic silver and a silver-chlorine system $44 \mathrm{~nm}$ in size were observed for $\mathrm{Ag} / \mathrm{SiO}{ }_{2} @ \mathrm{CMC}$. The silver concentration was estimated at a level of about 10 at.\% (bulk) and 2 at.\% (surface) for all of the systems (Table 4). The Raman investigations revealed that the synthesis procedure also influenced a structural modification within the silica network, which enabled interconnections to be formed between the positively charged silver and non-bonded oxygen atoms of the silica matrix. Also, the XRD studies showed that the Ag NPs were embedded in an amorphous silica network. These data are crucial in the context of antimicrobial and anticancer studies. Hence, the next part of the discussion focuses on the correlation between the physicochemical parameters and their impact on the biological systems.

One way to explain the antibacterial effect of silver-silica nanocomposites to look at a cell's environmental condition, metabolism, or wall structure of a specific bacteria or yeast. During the data interpretation, crucial information might be that L. plantarum bacteria are aerotolerant organisms that prefer anaerobic conditions, while the other three tested bacteria are aerobic and anaerobic. The addition of external modifiers such as silver to their surroundings can generate oxidation stress in cells, which transforms an excess of oxygen and releases hydrogen peroxide, thus inducing the bacteria's death [71]. Moreover, lower MBC values that are related to other strains can be explained through the synergistic interaction of metallic and oxidized $(\mathrm{AgO}, \mathrm{Ag} 2 \mathrm{O})$ silver as in the $\mathrm{Ag} / \mathrm{SiO} 2$ 
and $\mathrm{Ag} / \mathrm{SiO}_{2} @ \mathrm{AS}$ as well as metallic and clustered silver in the silver chloride configuration as in $\mathrm{Ag} / \mathrm{SiO}_{2} @ \mathrm{CMC}$. In turn, the lowest $\mathrm{MBC}$ values that were found for $\mathrm{Ag} / \mathrm{SiO}_{2}$ could have resulted from the slightly higher atomic concentration of silver in the reference sample relative to the other systems (Table 4). The other bacterial strains were 10- or 100-fold less affected on the silver-silica nanocomposites than on L. plantarum and the ionic reference (Table 5). At first glance, it appears that two tested Gram-positive bacteria interact differently on the Ag NPs, suggesting a different mechanism responsible for cell death in S. aureus than in the case of L. plantarum. According to Feng et al. [72], silver nanoparticles in the initial stage may affect the DNA molecules' replication ability, while after the lengthy exposure may provide the cell wall breakdown and release the cell's contents into the environment. Moreover, a long-term silver interaction could damage the recombinase A protein (recA) or affect the transcription, translation, and post-translational of the recA gene, which would actively reduce the possibility of damaged DNA being repaired. Similar antimicrobial effects were also reported for E. coli [72-74]. According to these reports, the similar MBC values that were obtained for E. coli and $S$. aureus led to the supposition that the cell death mechanism may be linked to silver ions that are released from the surface of the Ag NPs into the inside of bacteria and its interaction with the sulfur- and phosphorus-containing compounds. In turn, the wall structure differences between the Gram-positive and Gram-negative bacteria appear to have a negligible impact on cell death, despite the presence of lipopolysaccharide in the cell wall, which should help to trap and block the positive charges of silver. This is also contradictory with the literature data that illustrates that Gram-negative bacteria are less sensitive to Ag NPs than Gram-positive bacteria [75]. The impact of the particle shape and size on the cell membrane, which was estimated for the two systems $\left(\mathrm{Ag} / \mathrm{SiO}_{2}\right.$ and $\left.\mathrm{Ag} / \mathrm{SiO}_{2} @ \mathrm{AS}\right)$ to be well below $10 \mathrm{~nm}$ and a mutual interaction of the metallic and oxidized forms of silver can also not be excluded. According to the literature, a similar combination of Ag NPs with spherical (20 $\mathrm{nm}$ ) or irregular shapes (5-10 $\mathrm{nm})$ disturbed the proper functioning of bacteria cells [76,77]. Other results were observed for $\mathrm{Ag} / \mathrm{SiO}_{2} @ \mathrm{CMC}$, which mainly concerned Gram-positive (S. aureus) and Gram-negative ( $P$. aeruginosa) bacteria. One possible explanation may be the low concentration of silver and its chemical trapping in the silver-chlorine system, limiting the release of silver ions into the environment (data not shown). Another hypothesis may correlate with a much higher silver particle size estimated as $\mathrm{d}=(44.1 \pm 2.3) \mathrm{nm}$, while the most toxic objects were nanoparticles with sizes smaller than $10 \mathrm{~nm}[28,34,78]$. Additionally, a lower concentration of silver or a larger average size of the nanoparticles could lower intracellular bioavailability of silver and weaker contact between the cell and the particle [79-81]. Hence, the antimicrobial effect may only be explained through metallic silver interaction with the outer microbial membrane, which influences a modification of its lipid layer. A different situation was found for the yeast. The low MBC values had probably resulted in the yeast's specific cell wall composition, i.e., glucans, chitin, and mannoproteins, which causes rigidity in the overall wall structure and obstructs the possibility of connecting the silver particles to the surface, thereby reducing its positive impact.

Parallel to the nanocomposites' silver-silica antimicrobial properties, the anticancer activity against four cancer cell lines was tested. Among these cell lines, colon and breast represent the most common cancers in the entire population, especially in developed countries. In turn, glioblastomas and pancreatic cancer are the most aggressive tumors and have a poor prognosis, in which the overall five-year survival rate does not exceed 5\%. Unfortunately, determining the impact of silver or silver-based derivatives on human, normal, or cancer cells is problematic. One of the hypotheses reported by Hussain et al. suggests that the primary target sites of silver are the mitochondria, which are generally involved in maintaining the redox homeostasis in cells [82]. In this context, the cytotoxicity effect of silver may be associated with the size of the nanoparticles, i.e., $100 \mathrm{~nm}$-sized objects might not be able to enter cells, while a $10 \mathrm{~nm}$ sized particle can easily penetrate the interior of cells, which is prone to a strong release of silver ions. As a result, smaller Ag NPs could impact (i) the generation of reactive oxygen species (ROS), (ii) glutathione (GSH) depletion, (iii) the upregulation of heme oxygenase (HO-1) expression, (iv) a decrease in the enzyme activity of the superoxide dismutase (SOD) or (v) 
a mitochondrial membrane disruption [16-19,83]. Other studies demonstrated that Ag NPs might activate the redox-sensitive gene products such as the p38 mitogen-activated protein kinase (MAPK), nuclear factor E2-related factor-2 (Nrf2), and nuclear factor-kappa b (NF-kB) [84]. The ability of Ag NPs to induce an inflammatory response of the immune cells in vitro was also recently reported [34].

According to the experimental data, although the highest resistance was detected for the glioblastoma cell line, this type of cancer often exhibits drug-resistance. In turn, the lowest $\mathrm{IC}_{50}$ values were detected for MCF-7 and PANC-1. However, there were more significant differences between the tested nanocomposites for pancreatic cancer. Therefore, the PANC-1 cell line was selected for further studies, while the physicochemical data may help to understand the molecular mechanism of action of the silver-silica composite and its derivatives concerning this cancer cell line.

First of all, it is worth noting that both the PANC-1 and U-251 cell lines have a missense point mutation in the TP53 gene, which causes amino acid to change an arginine to histidine in codon $273[85,86]$. This mutation is responsible for increasing the oncogenic potential, the deregulation of the cell cycle, and the ability to metastasize [87]. To look more deeply at the problem mentioned above and to attempt to explain the cytotoxic effect of the synthesized silver-silica nanocomposites, a cell cycle inhibition test was performed on the selected PANC-1 model. The cell cycle studies revealed a checkpoint regulation and cell cycle inhibition in the $\mathrm{G}_{2} / \mathrm{M}$ phase in all of the studied systems (Figure $9 \mathrm{a}$ ). According to the literature data, cell cycle arrest in the $S$ and $G_{2} / M$ phases might correspond to silver nanoparticles' presence $[17,19,21,22]$. In contrast, the differences in a silica carrier structure seem to be less critical or even negligible. In this context, silver nanoparticles might cause morphological changes due to their interactions with cell permeability, ROS production, or an enzyme system alteration [88]. Ag NPs can also modulate the gene and protein expression, which are responsible for DNA repair [20], impact Chk1 kinase, prevent cdc25C activation, and repair DNA damage [89]. In turn, the effect of DNA damage may have resulted from direct interaction with the p53/p21 signaling pathway, which is responsible for the $\mathrm{G}_{2} / \mathrm{M}$ transition control system [90].

To shed more light on the type of cell death, the further possible pathways of the cell cycle inhibition were examined. The cells' exposure to the silver-silica systems for $48 \mathrm{~h}$ caused an increase in the apoptotic PANC-1 cell fraction (Figure 9b). More precisely, the number of apoptotic cells increased only slightly $(\sim 15 \%)$ relative to the reference $\mathrm{Ag} / \mathrm{SiO}_{2}$, while for other systems, it was even more than $50 \%$ compared to the control. Unexpectedly, this effect was negatively correlated with the silver concentration in the system (Table 4). Hence, it is worth looking at the other factors that might explain the studied systems' cytotoxicity effect. One hypothesis might be the metallic and oxidized silver nanoparticles' synergistic effect as detected for $\mathrm{Ag} / \mathrm{SiO}_{2}$ and $\mathrm{Ag} / \mathrm{SiO}_{2} @ \mathrm{AS}$. In those systems, $\mathrm{Ag}$ NPs are smaller than $10 \mathrm{~nm}$, enabling them to easily enter the interior of cells and promote the release of silver ions into the environment. Similar results were reported by Zielinska et al. [91] or Cameron et al. [83]. In turn, the $\mathrm{Ag} / \mathrm{SiO}_{2} @ \mathrm{CMC}$ system's high anticancer effect, which was characterized by a particle size that was larger than $44 \mathrm{~nm}$, could result from a slightly different mechanism of action. Here, more than $60 \%$ apoptotic or dead cells were observed (Figure $9 \mathrm{~b}$ ). The physicochemical interpretation indicated silver chloride and/or a metallic silver core with chloride, metallic, or clustered ions around the core, which can be an important factor that should be considered. Here, one can assume that the synergistic effect of the ions that were released from the surface of $\mathrm{AgCl}$ might correlate with the cytotoxicity data that was obtained for small-sized systems. Another hypothesis might be the impact of neutrally charged metallic silver, which can penetrate the lipid membrane cell and release the ions inside the cell. However, the molecular mechanisms of cancer cell death are still not fully understood and remain subject to further discussions.

One of the potential DNA damage factors is the generation of reactive oxygen species (ROS) [16, 19,92,93]. The total number of ROS in a time-dependent kinetic experiment was estimated for the most cytotoxic $\mathrm{Ag} / \mathrm{SiO}_{2} @ \mathrm{CMC}$ system (Figure 9c) to verify this hypothesis. The growing trend in the number of ROS that was observed in the first $6 \mathrm{~h}$ and then up to $24 \mathrm{~h}$ correlates with the release of the redox-active ions and enforces the cellular pathways that were postulated above. Hence, the ROS 
data can clarify the response to $\mathrm{G}_{2} / \mathrm{M}$ arrest, especially by looking more precisely at the alterations in the $\mathrm{G}_{2}$ checkpoint-associated proteins' levels in silver-silica and its derivatives-treated cells. In this context, it is crucial to consider that the checkpoints $G_{1} / S$ and the $G_{2} / M$ may correlate with the impact of protein $p 53$, which is known as the "guardian of the genome". It is also usually engaged in cellular stress, DNA-damage, or checkpoint failure [94].

On the other hand, mutations in the gene encoding $p 53$ are found in half of all cancers. Therefore, to look more deeply at the potential mechanism of silver action, a Western Blot test was performed exemplary on $\mathrm{Ag} / \mathrm{SiO}_{2} @ \mathrm{CMC}$. The obtained data confirmed previous results about cell cycle inhibition, apoptosis, or ROS generation hypothesis. Furthermore, immunoblot analyses revealed the upregulation of the stress-induced heme oxygenase (HO-1) protein and the lack of any significant influence on the $p 53$ protein, which is usually mutated in cancer cells, thus suggesting a $p 53$-independent mechanism of action. This data point to the induction of the oxidative stress in cells due to the presence of silver-silica nanocomposites and suggest that a mechanism of action has resulted from the induction of radical AS (Figure 9c). Additionally, another confirmation of the $\mathrm{G}_{2} / \mathrm{M}$ arrest may also be the data that illustrated no cyclin E expression changes that involve the $G_{1}$ phase of the cell cycle (Figure 9d). Moreover, our results seem to confirm the previous postulates of Eom et al., who reported that silver nanoparticles could affect the oxidative stress pathway-p38 MAPK via ROS formation, which then induces DNA damage and cell cycle arrest [84].

\section{Conclusions}

Chemical synthesis was used to prepare the silver-silica systems and their derivatives, which were fabricated by modifying the reference silver-silica system by sodium alginate and carboxymethylcellulose. The silver nanoparticles in the $\mathrm{Ag} / \mathrm{SiO} \mathrm{O}_{2}$ and $\mathrm{Ag} / \mathrm{SiO} \mathrm{O}_{2} @ \mathrm{AS}$ were distributed heterogeneity within the silica carrier, whereby the silver occurred in different states: oxides, metallic or ionic. The silver-silica system, which was chemically modified by carboxymethylcellulose, was characterized by larger silver nanoparticles $(\sim 44 \mathrm{~nm})$ that tended to strongly agglomerate. Chemically, this system was composed of metallic silver and silver that was clustered within the silver-chlorine system. The silver concentration was estimated at a level of about 10 at.\% (bulk) and 2 at.\% (surface) for all of the systems, which resulted in an antimicrobial and anticancer effect. It was found that the tiny silver nanoparticles that were found in $\mathrm{Ag} / \mathrm{SiO}_{2}$ and $\mathrm{Ag} / \mathrm{SiO}_{2} @ \mathrm{AS}$ influenced the cell growth inhibition, especially in E. coli, S. aureus, and L. Plantarum, while the massive silver nanoparticles in $\mathrm{Ag} / \mathrm{SiO}_{2} @ \mathrm{CMC}$ had a slightly lower antimicrobial effect. A similar cytotoxicity effect on the cancer cells was found for the physicochemical properties independently. The more detailed studies that were performed on the example of $\mathrm{Ag} / \mathrm{SiO}_{2} @ \mathrm{CMC}$ illustrated that the anticancer effect resulted from the reactive oxygen species generation.

Author Contributions: Conceptualization, M.D. and A.N.; methodology, M.D., A.N., K.D., K.M. (Krzysztof Matus), S.S., K.M. (Katarzyna Malarz), M.K.; software, M.D.; validation, A.N., K.D., K.M. (Krzysztof Matus), S.S., K.M. (Katarzyna Malarz), A.M.-W.; formal analysis, M.D.; investigation: Raman measurements, M.D.; XPS studies, A.N.; diffraction and SEM-EDS analysis, K.D., TEM-EDS experiment, K.M. (Krzysztof Matus); antimicrobial studies, S.S.; time-dependent measurement of the ROS level experiments, M.K.; cytotoxicity studies, cell cycle assay, annexin V binding assay and immunoblotting experiments, K.M. (Katarzyna Malarz); resources, M.D., A.N., K.M. (Krzysztof Matus), S.S., K.M. (Katarzyna Malarz), M.K.; data curation, M.D.; writing—original draft preparation, M.D., A.N.; analyse the biological data (anticancer studies) and wrote their interpretation, A.M.-W.; writing-review and editing, M.D., A.N., S.S., K.D.; visualization, M.D., A.N., K.M. (Krzysztof Matus), S.S., K.M. (Katarzyna Malarz); supervision, M.D., S.S., A.M.-W.; project administration, M.D.; funding acquisition, K.M. (Katarzyna Malarz), K.D., M.D., S.S. All authors have read and agreed to the published version of the manuscript.

Funding: This research was funded by the National Science Centre (NCN), based on the decision 2016/23/N/NZ7/00351 (K.M. (Katarzyna Malarz)), 2017/25/N/ST8/01479 (K.D.), 2017/26/D/ST8/01117 (M.D.) and 2017/26/D/NZ9/00448 (S.S.).

Acknowledgments: We are extremely grateful to G. Kramer-Marek from The Institute of Cancer Research in London, England, for providing the glioblastoma cell line U-251. 
Conflicts of Interest: The authors declare no conflict of interest. The funders had no role in the design of the study; in the collection, analyses, or interpretation of data; in the writing of the manuscript, or in the decision to publish the results.

\section{References}

1. Jamil, B.; Javed, R.; Qazi, A.S.; Syed, M.A. Nanomaterials: Toxicity, Risk Managment and Public Perception. In Nanomaterials: Ecotoxicity, Safety and Public Perception; Rai, M., Biswas, J.K., Eds.; Springer International Publishing: Cham, Switzerland, 2018; pp. 283-304. ISBN 978-3-030-05144-0.

2. Buffat, P.; Borel, J.-P. Size effect on the melting temperature of gold particles. Phys. Rev. A 1976, 13, $2287-2298$. [CrossRef]

3. Ercolessi, F.; Andreoni, W.; Tosatti, E. Melting of small gold particles: Mechanism and size effects. Phys. Rev. Lett. 1991, 66, 911-914. [CrossRef] [PubMed]

4. Singh, A.K.; Bhadauria, A.S.; Kumar, P.; Bera, H.; Saha, S. 2-Bioactive and drug-delivery potentials of polysaccharides and their derivatives. In Polysaccharide Carriers for Drug Delivery; Maiti, S., Jana, S., Eds.; Woodhead Publishing: Swaston, Cambridge, UK, 2019; pp. 19-48. ISBN 978-0-08-102553-6.

5. Yadav, H.; Karthikeyan, C. 1-Natural polysaccharides: Structural features and properties. In Polysaccharide Carriers for Drug Delivery; Maiti, S., Jana, S., Eds.; Woodhead Publishing: Swaston, Cambridge, UK, 2019; pp. 1-17. ISBN 978-0-08-102553-6.

6. Orive, G.; Ponce, S.; Hernández, R.M.; Gascón, A.R.; Igartua, M.; Pedraz, J.L. Biocompatibility of microcapsules for cell immobilization elaborated with different type of alginates. Biomaterials 2002, 23, 3825-3831. [CrossRef]

7. Finotelli, P.V.; Da, D.S.; Sola-Penna, M.; Rossi, A.M.; Farina, M.; Andrade, L.R.; Takeuchi, A.Y.; Rocha-Leão, M.H. Microcapsules of alginate/chitosan containing magnetic nanoparticles for controlled release of insulin. Colloids Surf. B Biointerfaces 2010, 81, 206-211. [CrossRef]

8. Langer, R.; Vacanti, J.P. Tissue engineering. Science 1993, 260, 920-926. [CrossRef]

9. Lee, K.Y.; Mooney, D.J. Hydrogels for tissue engineering. Chem. Rev. 2001, 101, 1869-1879. [CrossRef]

10. Konarska, Z.; Gieruszczak-Białek, D.; Pieścik-Lech, M.; Skórka, A.; Szajewska, H. Alginiany w leczeniu refluksu żołądkowo-przełykowego u dzieci: Przegląd systematyczny badań z randomizacją. Pediatr. Pol. 2015, 90, 20-25. [CrossRef]

11. Rajalekshmy, G.P.; Lekshmi Devi, L.; Joseph, J.; Rekha, M.R. 2-An overview on the potential biomedical applications of polysaccharides. In Functional Polysaccharides for Biomedical Applications; Maiti, S., Jana, S., Eds.; Woodhead Publishing: Swaston, Cambridge, UK, 2019; pp. 33-94. ISBN 978-0-08-102555-0.

12. Anita, B.B.; Thatheyus, A.J.; Ramya, D. Biodegradation of Carboxymethyl Cellulose using Aspergillus flavus. Sci. Int. 2013, 1, 85-91. [CrossRef]

13. Hollabaugh, C.B.; Burt, L.H.; Walsh, A.P. Carboxymethylcellulose. Uses and Applications. Ind. Eng. Chem. 1945, 37, 943-947. [CrossRef]

14. Wang, C.; Gao, X.; Chen, Z.; Chen, Y.; Chen, H. Preparation, Characterization and Application of Polysaccharide-Based Metallic Nanoparticles: A Review. Polymers 2017, 9, 689. [CrossRef]

15. Buttacavoli, M.; Albanese, N.N.; Cara, G.D.; Alduina, R.; Faleri, C.; Gallo, M.; Pizzolanti, G.; Gallo, G.; Feo, S.; Baldi, F.; et al. Anticancer activity of biogenerated silver nanoparticles: An integrated proteomic investigation. Oncotarget 2018, 9, 9685-9705. [CrossRef] [PubMed]

16. Lee, Y.-H.; Cheng, F.-Y.; Chiu, H.-W.; Tsai, J.-C.; Fang, C.-Y.; Chen, C.-W.; Wang, Y.-J. Cytotoxicity, oxidative stress, apoptosis and the autophagic effects of silver nanoparticles in mouse embryonic fibroblasts. Biomaterials 2014, 35, 4706-4715. [CrossRef] [PubMed]

17. AshaRani, P.V.; Low, K.M.G.; Hande, M.P.; Valiyaveettil, S. Cytotoxicity and Genotoxicity of Silver Nanoparticles in Human Cells. ACS Nano 2009, 3, 279-290. [CrossRef] [PubMed]

18. Arora, S.; Jain, J.; Rajwade, J.M.; Paknikar, K.M. Cellular responses induced by silver nanoparticles: In vitro studies. Toxicol. Lett. 2008, 179, 93-100. [CrossRef] [PubMed]

19. Chairuangkitti, P.; Lawanprasert, S.; Roytrakul, S.; Aueviriyavit, S.; Phummiratch, D.; Kulthong, K.; Chanvorachote, P.; Maniratanachote, R. Silver nanoparticles induce toxicity in A549 cells via ROS-dependent and ROS-independent pathways. Toxicol. In Vitro 2013, 27, 330-338. [CrossRef] [PubMed] 
20. AshaRani, P.; Sethu, S.; Lim, H.K.; Balaji, G.; Valiyaveettil, S.; Hande, M.P. Differential regulation of intracellular factors mediating cell cycle, DNA repair and inflammation following exposure to silver nanoparticles in human cells. Genome Integr. 2012, 3, 2. [CrossRef]

21. Kang, S.J.; Lee, Y.J.; Lee, E.-K.; Kwak, M.-K. Silver nanoparticles-mediated G2/M cycle arrest of renal epithelial cells is associated with NRF2-GSH signaling. Toxicol. Lett. 2012, 211, 334-341. [CrossRef]

22. Liu, W.; Wu, Y.; Wang, C.; Li, H.C.; Wang, T.; Liao, C.Y.; Cui, L.; Zhou, Q.F.; Yan, B.; Jiang, G.B. Impact of silver nanoparticles on human cells: Effect of particle size. Nanotoxicology 2010, 4, 319-330. [CrossRef]

23. Han, J.W.; Gurunathan, S.; Jeong, J.-K.; Choi, Y.-J.; Kwon, D.-N.; Park, J.-K.; Kim, J.-H. Oxidative stress mediated cytotoxicity of biologically synthesized silver nanoparticles in human lung epithelial adenocarcinoma cell line. Nanoscale Res. Lett. 2014, 9, 459. [CrossRef]

24. Miethling-Graff, R.; Rumpker, R.; Richter, M.; Verano-Braga, T.; Kjeldsen, F.; Brewer, J.; Hoyland, J.; Rubahn, H.-G.; Erdmann, H. Exposure to silver nanoparticles induces size- and dose-dependent oxidative stress and cytotoxicity in human colon carcinoma cells. Toxicol. In Vitro 2014, 28, 1280-1289. [CrossRef]

25. Lin, J.; Huang, Z.; Wu, H.; Zhou, W.; Jin, P.; Wei, P.; Zhang, Y.; Zheng, F.; Zhang, J.; Xu, J.; et al. Inhibition of autophagy enhances the anticancer activity of silver nanoparticles. Autophagy 2014, 10, 2006-2020. [CrossRef]

26. Sarathy, V.; Tratnyek, P.G.; Nurmi, J.T.; Baer, D.R.; Amonette, J.E.; Chun, C.L.; Penn, R.L.; Reardon, E.J. Aging of Iron Nanoparticles in Aqueous Solution: Effects on Structure and Reactivity. J. Phys. Chem. C 2008, 112, 2286-2293. [CrossRef]

27. Sotiriou, G.A.; Pratsinis, S.E. Engineering nanosilver as an antibacterial, biosensor and bioimaging material. Curr. Opin. Chem. Eng. 2011, 1, 3-10. [CrossRef] [PubMed]

28. Lok, C.-N.; Ho, C.-M.; Chen, R.; He, Q.-Y.; Yu, W.-Y.; Sun, H.; Tam, P.K.-H.; Chiu, J.-F.; Che, C.-M. Silver nanoparticles: Partial oxidation and antibacterial activities. J. Biol. Inorg. Chem. 2007, 12, 527-534. [CrossRef] [PubMed]

29. Xiu, Z.; Zhang, Q.; Puppala, H.L.; Colvin, V.L.; Alvarez, P.J.J. Negligible Particle-Specific Antibacterial Activity of Silver Nanoparticles. Nano Lett. 2012, 12, 4271-4275. [CrossRef] [PubMed]

30. Benn, T.M.; Westerhoff, P. Nanoparticle Silver Released into Water from Commercially Available Sock Fabrics. Environ. Sci. Technol. 2008, 42, 4133-4139. [CrossRef] [PubMed]

31. Navarro, E.; Piccapietra, F.; Wagner, B.; Marconi, F.; Kaegi, R.; Odzak, N.; Sigg, L.; Behra, R. Toxicity of silver nanoparticles to Chlamydomonas reinhardtii. Environ. Sci. Technol. 2008, 42, 8959-8964. [CrossRef] [PubMed]

32. Sotiriou, G.A.; Pratsinis, S.E. Antibacterial activity of nanosilver ions and particles. Environ. Sci. Technol. 2010, 44, 5649-5654. [CrossRef]

33. Zhang, X.-F.; Liu, Z.-G.; Shen, W.; Gurunathan, S. Silver Nanoparticles: Synthesis, Characterization, Properties, Applications and Therapeutic Approaches. Int. J. Mol. Sci. 2016, 17, 1534. [CrossRef]

34. Carlson, C.; Hussain, S.M.; Schrand, A.M.; Braydich-Stolle, L.K.; Hess, K.L.; Jones, R.L.; Schlager, J.J. Unique Cellular Interaction of Silver Nanoparticles: Size-Dependent Generation of Reactive Oxygen Species. J. Phys. Chem. B 2008, 112, 13608-13619. [CrossRef]

35. Yoon, S.H.; Lee, J.H.; Lee, P.C.; Nam, J.D.; Jung, H.-C.; Oh, Y.S.; Kim, T.S.; Lee, Y. kwan Sintering and consolidation of silver nanoparticles printed on polyimide substrate films. Macromol. Res. 2009, 17, 568-574. [CrossRef]

36. Lei, Z.W.; Liu, M.; Ge, W.; Fu, Z.P.; Reinhardt, K.; Knize, R.J.; Lu, Y. Morphology and optical absorption change of Ag/SiO2 core-shell nanoparticles under thermal annealing. Appl. Phys. Lett. 2012, 101, 083903. [CrossRef]

37. Pourali, P.; Baserisalehi, M.; Afsharnezhad, S.; Behravan, J.; Ganjali, R.; Bahador, N.; Arabzadeh, S. The effect of temperature on antibacterial activity of biosynthesized silver nanoparticles. Biometals 2013, 26, 189-196. [CrossRef] [PubMed]

38. Oberdörster, G.; Stone, V.; Donaldson, K. Toxicology of nanoparticles: A historical perspective. Nanotoxicology 2007, 1, 2-25. [CrossRef]

39. Akhavan, O.; Azimirad, R.; Moshfegh, A.Z. Low temperature self-agglomeration of metallic Ag nanoparticles on silica sol-gel thin films. J. Phys. D Appl. Phys. 2008, 41, 195305. [CrossRef]

40. Augustine, R.; Rajarathinam, K. Synthesis and characterization of silver nanoparticles and its immobilization on alginate coated sutures for the prevention of surgical wound infections and the in vitro release studies. Int. J. Nano Dimens. 2012, 2, 205-212. [CrossRef] 
41. Kumar, H.; Gaur, A.; Kumar, S.; Park, J.-W. Development of silver nanoparticles-loaded CMC hydrogel using bamboo as a raw material for special medical applications. Chem. Pap. 2019, 73, 953-964. [CrossRef]

42. Prema, P.; Thangapandiyan, S.; Immanuel, G. CMC stabilized nano silver synthesis, characterization and its antibacterial and synergistic effect with broad spectrum antibiotics. Carbohydr. Polym. 2016, 158, 141-148. [CrossRef]

43. Lengert, E.; Saveleva, M.; Abalymov, A.; Atkin, V.; Wuytens, P.C.; Kamyshinsky, R.; Vasiliev, A.L.; Gorin, D.A.; Sukhorukov, G.B.; Skirtach, A.G.; et al. Silver Alginate Hydrogel Micro- and Nanocontainers for Theranostics: Synthesis, Encapsulation, Remote Release and Detection. ACS Appl. Mater. Interfaces 2017, 9, 21949-21958. [CrossRef]

44. Peszke, J.; Dulski, M.; Nowak, A.; Balin, K.; Zubko, M.; Sułowicz, S.; Nowak, B.; Piotrowska-Seget, Z.; Talik, E.; Wojtyniak, M.; et al. Unique properties of silver and copper silica-based nanocomposites as antimicrobial agents. RSC Adv. 2017, 7, 28092-28104. [CrossRef]

45. Guerrero-Martínez, A.; Pérez-Juste, J.; Liz-Marzán, L.M. Recent progress on silica coating of nanoparticles and related nanomaterials. Adv. Mater. Weinh. 2010, 22, 1182-1195. [CrossRef] [PubMed]

46. Dulski, M.; Peszke, J.; Włodarczyk, J.; Sułowicz, S.; Piotrowska-Seget, Z.; Dudek, K.; Podwórny, J.; Malarz, K.; Mrozek-Wilczkiewicz, A.; Zubko, M.; et al. Physicochemical and structural features of heat treated silver-silica nanocomposite and their impact on biological properties. Mater. Sci. Eng. C 2019, 103, 109790. [CrossRef] [PubMed]

47. Laskowski, L.; Laskowska, M.; Fijalkowski, K.; Piech, H.; Jelonkiewicz, J.; Jaskulak, M.; Gnatowski, A.; Dulski, M. New Class of Antimicrobial Agents: SBA-15 Silica Containing Anchored Copper Ions. J. Nanomater. 2017, 2017, 1-12. [CrossRef]

48. Dudek, K.; Podwórny, J.; Dulski, M.; Nowak, A.; Peszke, J. X-ray investigations into silica/silver nanocomposite. Powder Diffr. 2017, 32, S82-S86. [CrossRef]

49. Peitl, O.; Dutra Zanotto, E.; Hench, L.L. Highly bioactive P2O5-Na2O-CaO-SiO 2 glass-ceramics. J. Non Cryst. Solids 2001, 292, 115-126. [CrossRef]

50. Nowak, A.; Szade, J.; Talik, E.; Ratuszna, A.; Ostafin, M.; Peszke, J. Structural, spectroscopic and biological investigation of copper oxides nanoparticles with various capping agents. Mater. Chem. Phys. 2014, 145, 465-470. [CrossRef]

51. Gangishetty, M.K.; Scott, R.W.J.; Kelly, T.L. Thermal degradation mechanism of triangular ${\mathrm{Ag} @ S i \mathrm{O}_{2}}$ nanoparticles. Dalton Trans. 2016, 45, 9827-9834. [CrossRef]

52. Nowak, A.; Szade, J.; Talik, E.; Zubko, M.; Wasilkowski, D.; Dulski, M.; Balin, K.; Mrozik, A.; Peszke, J. Physicochemical and antibacterial characterization of ionocity $\mathrm{Ag} / \mathrm{Cu}$ powder nanoparticles. Mater. Charact. 2016, 117, 9-16. [CrossRef]

53. Li, Z.; Jia, L.; Li, Y.; He, T.; Li, X.-M. Ammonia-free preparation of $\mathrm{Ag} @ \mathrm{SiO}_{2}$ core/shell nanoparticles. Appl. Surf. Sci. 2015, 345, 122-126. [CrossRef]

54. Suppi, S.; Kasemets, K.; Ivask, A.; Künnis-Beres, K.; Sihtmäe, M.; Kurvet, I.; Aruoja, V.; Kahru, A. A novel method for comparison of biocidal properties of nanomaterials to bacteria, yeasts and algae. J. Hazard. Mater. 2015, 286, 75-84. [CrossRef]

55. Magaña, S.M.; Quintana, P.; Aguilar, D.H.; Toledo, J.A.; Ángeles-Chávez, C.; Cortés, M.A.; León, L.; Freile-Pelegrín, Y.; López, T.; Sánchez, R.M.T. Antibacterial activity of montmorillonites modified with silver. J. Mol. Catal. A Chem. 2008, 281, 192-199. [CrossRef]

56. McMillan, P. A Raman spectroscopic study of glasses in the system CaO-MgO-SiO 2 . Am. Mineral. 1984, 69, 645-659.

57. Han, C.; Chen, M.; Rasch, R.; Yu, Y.; Zhao, B. Structure Studies of Silicate Glasses by Raman Spectroscopy. In Advances in Molten Slags, Fluxes and Salts, Proceedings of the 10th International Conference on Molten Slags, Fluxes and Salts, Washigton, DC, USA, 22-25 May 2016; Reddy, R.G., Chaubal, P., Pistorius, P.C., Pal, U., Eds.; Springer International Publishing: Cham, Switzerland, 2016; pp. 175-182.

58. Socrates, G. Infrared and Raman Characteristic Group Frequencies: Tables and Charts, 3rd ed.; Wiley: Chichester, West Sussex, UK, 2001; ISBN 978-0-471-85298-8.

59. Alessi, A.; Agnello, S.; Buscarino, G.; Gelardi, F.M. Structural properties of core and surface of silica nanoparticles investigated by Raman spectroscopy. J. Raman Spectrosc. 2013, 44, 810-816. [CrossRef] 
60. Vaccaro, G.; Agnello, S.; Buscarino, G.; Gelardi, F.M. Thermally Induced Structural Modification of Silica Nanoparticles Investigated by Raman and Infrared Absorption Spectroscopies. J. Phys. Chem. C 2010, 114, 13991-13997. [CrossRef]

61. Geissberger, A.E.; Galeener, F.L. Raman studies of vitreous $\mathrm{SiO}_{2}$ versus fictive temperature. Phys. Rev. B 1983, 28, 3266-3271. [CrossRef]

62. Robinet, L.; Coupry, C.; Eremin, K.; Hall, C. The use of Raman spectrometry to predict the stability of historic glasses. J. Raman Spectrosc. 2006, 37, 789-797. [CrossRef]

63. Sidgwick, N.V. The Chemical Elements and Their Compounds; Oxford Clarendon Press: Oxford, UK, 1950; Volume 1.

64. Matson, D.W.; Sharma, S.K.; Philpotts, J.A. The structure of high-silica alkali-silicate glasses. A Raman spectroscopic investigation. J. Non Cryst. Solids 1983, 58, 323-352. [CrossRef]

65. Sharma, S.K. Raman investigation of ring configurations in vitreous silica. Nature 1981, $292,140-141$. [CrossRef]

66. Viard, J.; Beche, E.; Perarnau, D.; Berjoan, R.; Durand, J. XPS and FTIR study of silicon oxynitride thin films. J. Eur. Ceram. Soc. 1997, 17, 2025-2028. [CrossRef]

67. Sang, J.; Aisawa, S.; Hirahara, H.; Kudo, T.; Mori, K. Self-reduction and size controlled synthesis of silver nanoparticles on carbon nanospheres by grafting triazine-based molecular layer for conductivity improvement. Appl. Surf. Sci. 2016, 364, 110-116. [CrossRef]

68. Calderon, S.V.; Galindo, R.E.; Benito, N.; Palacio, C.; Cavaleiro, A.; Carvalho, S. Ag+ release inhibition from $\mathrm{ZrCN}-\mathrm{Ag}$ coatings by surface agglomeration mechanism: Structural characterization. J. Phys. D Appl. Phys. 2013, 46, 325303. [CrossRef]

69. Shah, Z.H.; Wang, J.; Ge, Y.; Wang, C.; Mao, W.; Zhang, S.; Lu, R. Highly enhanced plasmonic photocatalytic activity of $\mathrm{Ag} / \mathrm{AgCl} / \mathrm{TiO}_{2}$ by $\mathrm{CuO}$ co-catalyst. J. Mater. Chem. A 2015, 3, 3568-3575. [CrossRef]

70. Wang, D.H.; Hu, Y.; Zhao, J.J.; Zeng, L.L.; Tao, X.M.; Chen, W. Holey reduced graphene oxide nanosheets for high performance room temperature gas sensing. J. Mater. Chem. A 2014, 2, 17415-17420. [CrossRef]

71. Kędziora, A.; Speruda, M.; Krzyżewska, E.; Rybka, J.; Łukowiak, A.; Bugla-Płoskońska, G. Similarities and Differences between Silver Ions and Silver in Nanoforms as Antibacterial Agents. Int. J. Mol. Sci. 2018, 19, 444. [CrossRef] [PubMed]

72. Feng, Q.L.; Wu, J.; Chen, G.Q.; Cui, F.Z.; Kim, T.N.; Kim, J.O. A mechanistic study of the antibacterial effect of silver ions on Escherichia coli and Staphylococcus aureus. J. Biomed. Mater. Res. 2000, 52, 662-668. [CrossRef]

73. Cox, M.M. The bacterial RecA protein: Structure, function and regulation. In Molecular Genetics of Recombination; Aguilera, A., Rothstein, R., Eds.; Topics in Current Genetics; Springer: Berlin/Heidelberg, Germany, 2007; pp. 53-94. ISBN 978-3-540-71021-9.

74. Li, W.-R.; Xie, X.-B.; Shi, Q.-S.; Duan, S.-S.; Ouyang, Y.-S.; Chen, Y.-B. Antibacterial effect of silver nanoparticles on Staphylococcus aureus. Biometals 2011, 24, 135-141. [CrossRef] [PubMed]

75. Lara, H.H.; Ayala-Nunez, N.V.; Ixtepan, T.L.d.C.; Rodriguez-Padilla, C. Bactericidal effect of silver nanoparticles against multidrug-resistant bacteria. World J. Microbiol. Biotechnol. 2010, 26, 615-621. [CrossRef]

76. Morones, J.R.; Elechiguerra, J.L.; Camacho, A.; Holt, K.; Kouri, J.B.; Ramírez, J.T.; Yacaman, M.J. The bactericidal effect of silver nanoparticles. Nanotechnology 2005, 16, 2346-2353. [CrossRef]

77. Salomoni, R.; Léo, P.; Montemor, A.F.; Rinaldi, B.G.; Rodrigues, M. Antibacterial effect of silver nanoparticles in Pseudomonas aeruginosa. Nanotechnol. Sci. Appl. 2017, 10, 115-121. [CrossRef]

78. Rangelova, N.; Aleksandrov, L.; Angelova, T.; Georgieva, N.; Müller, R. Preparation and characterization of $\mathrm{SiO}_{2} / \mathrm{CMC} / \mathrm{Ag}$ hybrids with antibacterial properties. Carbohydr. Polym. 2014, 101, 1166-1175. [CrossRef]

79. Hsiao, I.-L.; Hsieh, Y.-K.; Wang, C.-F.; Chen, I.-C.; Huang, Y.-J. Trojan-horse mechanism in the cellular uptake of silver nanoparticles verified by direct intra- and extracellular silver speciation analysis. Environ. Sci. Technol. 2015, 49, 3813-3821. [CrossRef]

80. Liu, J.; Sonshine, D.A.; Shervani, S.; Hurt, R.H. Controlled release of biologically active silver from nanosilver surfaces. ACS Nano 2010, 4, 6903-6913. [CrossRef]

81. Durán, N.; Durán, M.; de Jesus, M.B.; Seabra, A.B.; Fávaro, W.J.; Nakazato, G. Silver nanoparticles: A new view on mechanistic aspects on antimicrobial activity. Nanomedicine 2016, 12, 789-799. [CrossRef]

82. Hussain, S.M.; Hess, K.L.; Gearhart, J.M.; Geiss, K.T.; Schlager, J.J. In vitro toxicity of nanoparticles in BRL 3A rat liver cells. Toxicol. In Vitro 2005, 19, 975-983. [CrossRef] 
83. Cameron, S.J.; Hosseinian, F.; Willmore, W.G. A Current Overview of the Biological and Cellular Effects of Nanosilver. Int. J. Mol. Sci. 2018, 19, 2030. [CrossRef] [PubMed]

84. Eom, H.-J.; Choi, J. p38 MAPK Activation, DNA Damage, Cell Cycle Arrest and Apoptosis as Mechanisms of Toxicity of Silver Nanoparticles in Jurkat T Cells. Environ. Sci. Technol. 2010, 44, 8337-8342. [CrossRef] [PubMed]

85. Butz, J.; Wickstrom, E.; Edwards, J. Characterization of mutations and loss of heterozygosity of p53 and K-ras2 in pancreatic cancer cell lines by immobilized polymerase chain reaction. BMC Biotechnol. 2003, 3, 11. [CrossRef] [PubMed]

86. Leroy, B.; Girard, L.; Hollestelle, A.; Minna, J.D.; Gazdar, A.F.; Soussi, T. Analysis of TP53 Mutation Status in Human Cancer Cell Lines: A Reassessment. Hum. Mutat. 2014, 35, 756-765. [CrossRef] [PubMed]

87. Pitolli, C.; Wang, Y.; Mancini, M.; Shi, Y.; Melino, G.; Amelio, I. Do Mutations Turn p53 into an Oncogene? Int. J. Mol. Sci. 2019, 20, 6241. [CrossRef]

88. Jones, C.F.; Grainger, D.W. In vitro assessments of nanomaterial toxicity. Adv. Drug Deliv. Rev. 2009, 61, 438-456. [CrossRef]

89. Duan, J.; Yu, Y.; Li, Y.; Yu, Y.; Li, Y.; Zhou, X.; Huang, P.; Sun, Z. Toxic Effect of Silica Nanoparticles on Endothelial Cells through DNA Damage Response via Chk1-Dependent G2/M Checkpoint. PLoS ONE 2013, 8, e62087. [CrossRef] [PubMed]

90. Mytych, J.; Zebrowski, J.; Lewinska, A.; Wnuk, M. Prolonged Effects of Silver Nanoparticles on p53/p21 Pathway-Mediated Proliferation, DNA Damage Response and Methylation Parameters in HT22 Hippocampal Neuronal Cells. Mol. Neurobiol. 2017, 54, 1285-1300. [CrossRef] [PubMed]

91. Zielinska, E.; Zauszkiewicz-Pawlak, A.; Wojcik, M.; Inkielewicz-Stepniak, I. Silver nanoparticles of different sizes induce a mixed type of programmed cell death in human pancreatic ductal adenocarcinoma. Oncotarget 2017, 9, 4675-4697. [CrossRef]

92. Flores-López, L.Z.; Espinoza-Gómez, H.; Somanathan, R. Silver nanoparticles: Electron transfer, reactive oxygen species, oxidative stress, beneficial and toxicological effects. Mini review. J. Appl. Toxicol. 2019, 39, 16-26. [CrossRef] [PubMed]

93. Abdal Dayem, A.; Hossain, M.K.; Lee, S.B.; Kim, K.; Saha, S.K.; Yang, G.-M.; Choi, H.Y.; Cho, S.-G. The Role of Reactive Oxygen Species (ROS) in the Biological Activities of Metallic Nanoparticles. Int. J. Mol. Sci. 2017, 18, 120. [CrossRef] [PubMed]

94. Meulmeester, E.; Jochemsen, A.G. p53: A guide to apoptosis. Curr. Cancer Drug Targets 2008, 8, 87-97. [CrossRef] [PubMed]

Publisher's Note: MDPI stays neutral with regard to jurisdictional claims in published maps and institutional affiliations.

(C) 2020 by the authors. Licensee MDPI, Basel, Switzerland. This article is an open access article distributed under the terms and conditions of the Creative Commons Attribution (CC BY) license (http://creativecommons.org/licenses/by/4.0/). 